\title{
Sardine (Sardina pilchardus) larval dispersal in the Iberian Upwelling System, using coupled biophysical techniques
}

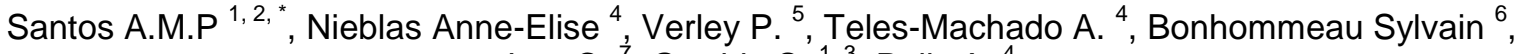 \\ Lett C. ${ }^{7}$, Garrido S. ${ }^{1,3}$, Peliz A. ${ }^{4}$
}

${ }^{1}$ Instituto Português do Mar e da Atmosfera (IPMA), Rua Alfredo Magalhães Ramalho, 6, 1449-006

Lisboa, Portugal

${ }^{2}$ Instituto Português do Mar e da Atmosfera (IPMA)/CCMAR, Rua Alfredo Magalhães Ramalho, 6,

1449-006 Lisboa, Portugal

${ }^{3}$ Instituto Português do Mar e da Atmosfera (IPMA)/MARE, Rua Alfredo Magalhães Ramalho, 6, 1449-

006 Lisboa, Portugal

${ }^{4}$ Instituto Dom Luiz (IDL), Faculdade de Ciencias da Universidade de Lisboa, Campo Grande, 1749-

016 Lisboa, Portugal.

${ }^{5}$ Institut de recherche pour le développement (IRD), Centre de Recherche Halieutique Méditerranéenne

et Tropicale (CRHMT), rue Jean Monnet, BP 171, 34203 Sète, France

${ }^{6}$ Institut français de recherche pour l'exploitation de la mer (IFREMER), CRHMT, Sète, France

${ }^{7}$ UMI IRD 209 UPMC UMMISCO,CRHMT, Avenue Jean Monnet, BP 171, Sète cedex, France

* Corresponding author : A. M. P. Santos, email address : amsantos@ipma.pt

\begin{abstract}
:
The European sardine (Sardina pilchardus) is the most important small pelagic fishery of the Western Iberia Upwelling Ecosystem (WIUE). Recently, recruitment of this species has declined due to changing environmental conditions. Furthermore, controversies exist regarding its population structure with barriers thought to exist between the Atlantic-Iberian Peninsula, Northern Africa, and the Mediterranean. Few studies have investigated the transport and dispersal of sardine eggs and larvae off lberia and the subsequent impact on larval recruitment variability. Here, we examine these issues using a Regional Ocean Modeling System climatology (1989-2008) coupled to the Lagrangian transport model, Ichthyop. Using biological parameters from the literature, we conduct simulations that investigate the effects of spawning patchiness, diel vertical migration behaviors, and egg buoyancy on the transport and recruitment of virtual sardine ichthyoplankton on the continental shelf. We find that release area, release depth, and month of release all significantly affect recruitment. Patchiness has no effect and diel vertical migration causes slightly lower recruitment. Egg buoyancy effects are significant and act similarly to depth of release. As with other studies, we find that recruitment peaks vary by latitude, explained here by the seasonal variability of offshore transport. We find weak, continuous alongshore transport between release areas, though a large proportion of simulated ichthyoplankton transport north to the Cantabrian coast (up to 27\%). We also show low level transport into Morocco (up to 1\%) and the Mediterranean (up to $8 \%$ ). The high proportion of local retention and low but consistent alongshore transport supports the idea of a series of metapopulations along this coast.
\end{abstract}




\section{Highlights}

- Larval sardine retention is highest near the release site (self-recruitment) - Release area, release depth, and month of release significantly affect recruitment. Retention and recruitment is very high in relation to other upwelling regions. - Transport to Cantabrian up to $27 \%$, Morocco up to $1 \%$ and Mediterranean up to $8 \%$ Results support the idea of a series of metapopulations along this region.

Keywords: Iberian Peninsula, Sardina pilchardus, larval dispersal, Lagrangian transport, Ichthyop, Regional Ocean Modeling System 


\section{INTRODUCTION}

The European sardine (Sardina pilchardus) comprises the most important small pelagic fishery in the Iberian and Canary Upwelling Ecosystems and is an important fishery for Portugal, Spain (Ferreira 1998, Santos et al. 2007), and Morocco (Kifani 1998, Arístegui et al. 2009). Information about recruitment variability and the spatial distribution and connectivity of populations is important for fisheries sustainability and management (Botsford et al. 2009). As another small pelagic fish, this species is short-lived, subject to natural fluctuations of productivity and heavily exploited, and thus its recruitment variability quickly translates to variability in population size (Brochier et al. 2008b, Field et al. 2009 and references herein, Malta et al. 2016). The recruitment of sardines off the Iberian Peninsula has declined in the last decades, which has been accompanied by changes in environmental conditions and exploitation in the spawning region (Borges et al. 1997, Santos et al. 2001, Guisande et al. 2001, Borges et al. 2003, Carrera et al. 2003, Santos et al., 2007, Santos et al., 2012, Malta et al., 2016). Environmental conditions, in conjunction with spawning and larval behavior, are generally thought to drive most recruitment variability, with high recruitment success occurring when eggs and larvae are retained in environmentally-favorable regions (Sinclair and Iles, 1989, Bakun 1996, Cury et al. 2000, Lowerre-Barbieri et al. 2017 and references herein). Likewise, barriers within the marine environment (e.g., ocean fronts or currents) impact the spatial distribution, connectivity and, thus, genetic diversity of fish populations (Cowen et al. 2007 and references herein). In this study, we aim to investigate the influence of ocean conditions on dispersal and retention of $S$. pilchardus eggs and larvae in the Iberian upwelling system to better understand how these small pelagic fish have adapted their reproductive strategies in a coastal upwelling system to ensure coastal retention and recruitment success.

The Iberian coast is the northern extent of the Canary Current Upwelling Ecosystem and 
summer upwelling conditions drive equatorward flow along the continental shelf and slope (Haynes et al. 1993, Peliz et al. 2002, Relvas et al. 2007). A narrow poleward undercurrent, the Iberian Poleward Current, also flows along the shelf and slope (Fig. 1; Frouin et al. 1999, Peliz et al. 2003), which intensifies in winter and becomes a surface jet. The east-west orientation of the Gulf of Cadiz, the southern extent of the Iberian Peninsula, has different circulation patterns and is strongly influenced by in- and outflow from the Mediterranean. The surface shelf circulation of the northern Gulf of Cadiz is dominate by two cyclonic circulation cells separated by Cape Santa Maria (Garcia-Lafuente et al., 2006) and by the Gulf of Cadiz Slope Current (Peliz et al. 2007a, 2009) that flows southeastward into the Mediterranean throughout the year (Fig. 1). Over this shelf, the currents usually respond to wind events on a synoptic scale, and these drive either a coastal upwelling-type flow in response to north-northwesterly winds with the eastward spreading of the cold waters that upwelled either at Cape São Vicente or farther north (Relvas et al. 2007), or a change to a downwelling flow in response to the short but frequent and intense easterly winds (TelesMachado et al. 2007).

Sardines spawn and recruit all along the Iberian coast (Bernal et al. 2007, Checkley et al. 2010), with one of the main spawning regions historically off the northwest Iberian coast $\left(40^{\circ} \mathrm{N}-41.5^{\circ} \mathrm{N}\right)($ Bernal et al. 2007). Spawning generally occurs in the late autumn and winter (October to March) (Figueiredo and Santos 1989; Ré et al. 1990, Coombs et al. 2006) when upwelling events are weak, rare or non-existent. In last decades, more winter upwelling events have been observed, which may have led to the loss of recruits via offshore transport (Borges et al. 1997, Santos et al. 2001, Borges et al. 2003). Previous studies have suggested that the effects of offshore transport may be modulated by the interaction of the Iberian Poleward Current with other local circulation features in the region, namely the Western Iberian Buoyant Plume (Santos et al. 2004, Santos et al. 2007). 


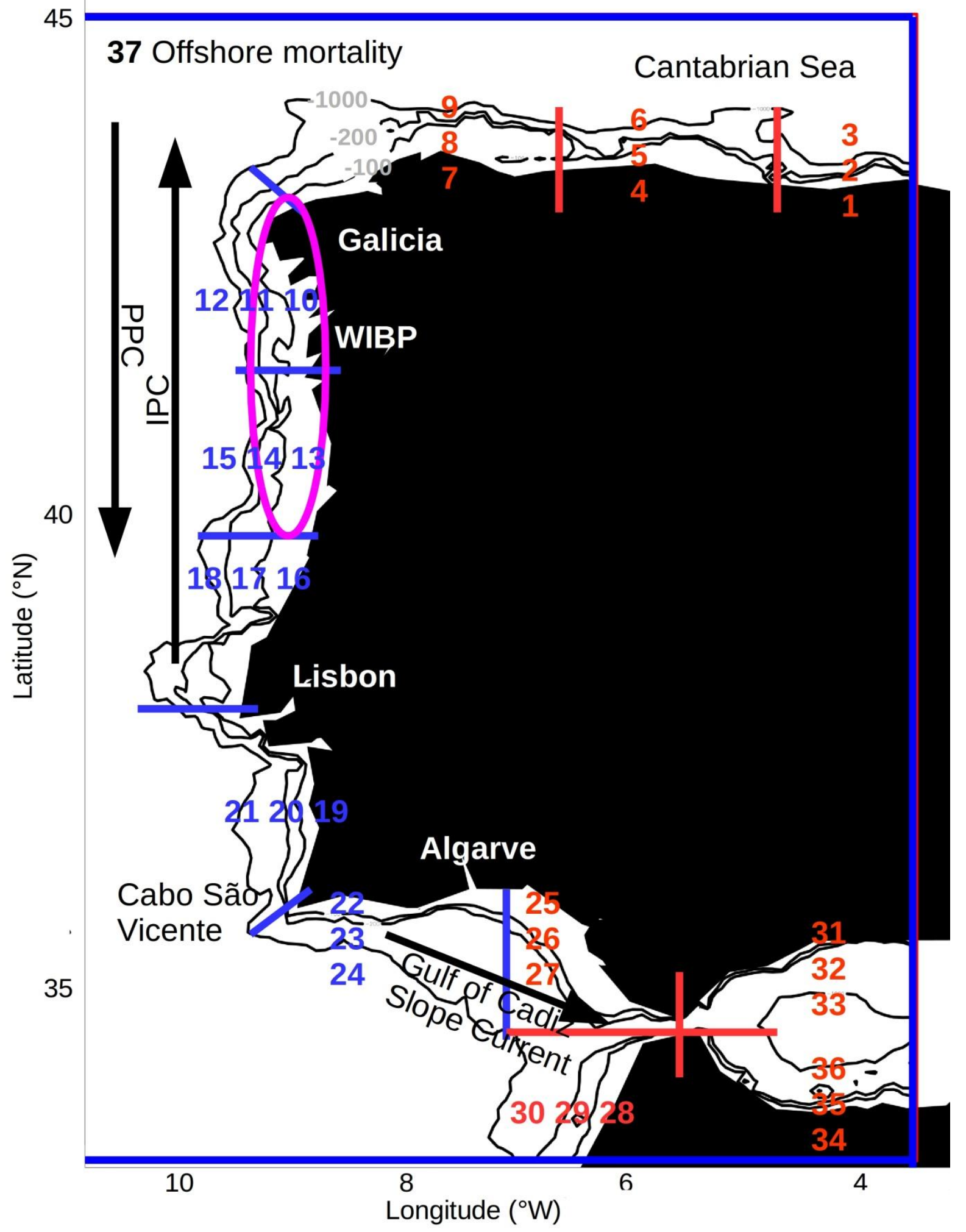

Figure 1. The zones of release (10-24), recruitment (1-36), and "mortality" (offshore transport, zone 37) for the Iberian Peninsula and northern Africa. WIBP-Western Iberian Buoyant Plume; IPC-Iberian Poleward Current; PPC-Portugal Current.

Local circulation features can also influence population dynamics of sardines. A 
controversy exists between studies that claim there is a population differentiation amongst the S. pilchardus of the Atlantic Iberia, NW Africa, and the Mediterranean Sea due to the oceanographic barrier at the Strait of Gibraltar (Silva 2003). Many studies find that Mediterranean stocks are isolated from Atlantic stocks (e.g., Baibai et al. 2012). Studies that date back to the 1920s (e.g., Fage 1920) show evidence of sardine subspecies differing between the Atlantic-Iberian subpopulation and the NW African and Mediterranean subpopulations (Parrish et al. 1989). Several recent genetic studies support this hypothesis, finding genetic differentiation between sardines of the different regions (e.g., Chlaida et al. 2009, Baibai et al. 2012). However, other genetic (Chlaida et al. 2006) and morphometric (Silva 2003) studies show that the Atlantic-Iberian and the NW African stocks do not differ significantly. These findings are supported by a recent dispersal modeling study that observed high degrees of connectivity between Iberia and Morocco (Oliveira and Stratoudakis 2008).

This study aims to investigate the influence of climatological ocean conditions, the spatial and temporal distribution of sardine spawning, and larval behavior on dispersal, retention, and recruitment of $S$. pilchardus eggs and larvae in the Iberian upwelling system. We investigate the influence of geographical and biological parameters and the relationship of transport and recruitment of simulated ichthyoplankton to regional circulation patterns. To do this, we use a Regional Ocean Modeling System (ROMS)-based model (Peliz et al. 2007a, 2007b, and 2009, Teles-Machado et al. 2016) to force a Lagrangian transport model that simulates the dispersal and behaviors of the early life of fish. We test the influence of biological parameters on dispersal, such as different egg densities and vertical migration schemes for larvae. This coupled biophysical technique is valuable to understand the interaction between biology and the environment, and has been used for other major upwelling systems (e.g., Huggett et al. 2003, Brochier et al. 2008a, Carr et al. 2008) and the African part of the Canary Current Upwelling Ecosystem (Brochier et al. 2008b, 2011). This 
coupled biophysical technique is valuable to understand the interaction between biology and the environment. It has been used for modelling the dispersal of sardine and anchovy ichthyoplankton in the Benguela (e.g., Huggett et al. 2003, Miller et al. 2006, Koné et al. 2013, Lett et al. 2015), Humboldt (Brochier et al. 2008a, Parada et al. 2012, Brochier et al. 2013, Xu et al. 2015), and California (Carr et al. 2008, Fiechter et al. 2015) Current upwelling ecosystems. It has also been used in the African part of the Canary Current upwelling ecosystem off Morocco (Brochier et al. 2008b, 2011) and Mauritania-Senegal (Mbaye et al. 2015). In the northern part of this ecosystem (Iberian Peninsula), studies of sardine dispersal off the Portuguese coast are scarce (Santos et al. 2004, Santos et al. 2005, Oliveira and Stratoudakis 2008, García-García et al. 2016).

Santos et al. (2004) used a very simplified transport model and do not include biological parameters but they have an excellent data set from physics (CTD, water samples and current meters) to plankton (fluorometer data and bongo nets). Santos et al. (2005) developed a biophysical model to simulate the effects of temperature and food availability on the survival of larval sardine during winter (spawning season) upwelling and downwelling events. Their simulations support the hypothesis that upwelling events during the spawning season may have a negative impact on larval survival (Borges et al., 2003). Since at the time of the study there were not larval sardine parameterizations the authors used the ones for northern anchovy (Engraulis mordax) and Pacific sardine (Sardinops sagax) in the California Current Upwelling System. At the same time, the influence of buoyant plumes in retention (Santos et al., 2004) was not included in the model and the authors also refer that the resolution of the circulation model could be problematic for these transport studies. Oliveira and Stratoudakis (2008), using satellite-derived data, simulated the dispersal of sardine eggs and larvae as passive particles in the whole Canary Current Upwelling System (Iberia and NW Africa). Although the results provide useful patterns for the study of sardine dynamics, the authors 
recognize the limitations of satellite-derived surface currents near the coast which is a limitation for the study of the transport of sardine eggs and larvae in the continental shelf of this system. García-García et al. (2016) demonstrated the potential larval connectivity that exists between the Cantabrian Sea and northern Portugal and their model provides information about the environmental variability (temperature and food availability) that could affect the survival of early life stages. However, the study only simulates one low recruitment year and contrasting high and low recruitment was not tested, prohibiting more definitive conclusions about connectivity variability.

To our knowledge, we are the first study with a long time span (20 years) focused on the main spawning/recruitment grounds of the Atlantic Iberian sardine stock (from the Gulf of Cadiz to Cantabrian Sea) that uses a climatological mean ocean circulation computed over a 20 year period and a Lagrangian transport model that incorporates biological parameters of sardine larvae. 


\section{METHODS}

\section{Hydrodynamic model}

The numerical ocean model is ROMS-based (Shchepetkin and McWilliams 2005) with 2-way nesting capabilities (Debreu et al. 2011). Applications of this model to the western Iberian margin have been under continuous development and improvement (see Peliz et al. 2003, 2007 a, b, 2009, 2013 and Teles-Machado et al. 2016). In its present configuration (TelesMachado et al. 2016), the model resolves the important processes driving the western Iberian margin circulation including the outflow of the main rivers and realistic exchanges with the Mediterranean (Peliz et al. 2013). The model consists of a set of embedded grids of varying resolution, the smallest of which covers the western Iberian margin at a resolution of $2.3 \mathrm{~km}$ and corresponds to the grid we use in the present study (Fig. 1). The model is forced with a $27 \mathrm{~km}$ resolution Weather, Research and Forecast dynamic downscaling of an ERA-Interim reanalysis (Soares et al. 2012). The high resolution simulation covers a two decade period from 1989-2008, with an archive time of 5 days. We computed a climatological mean year at 5 day time intervals over the 20 years of simulations. It should be noted that climatological velocity fields will smooth mesoscale variability. Temperature, salinity and three dimensional velocity fields are stored in full spatial resolution to be used by the Lagrangian tool.

\section{Particle dispersal model}

To model the Lagrangian transport of sardine eggs and larvae, we use the free online Java tool, Ichthyop (version 3.1) (Lett et al. 2008). This tool enables the investigation of larval dispersal by integrating ROMS output and the biological behavior of ichthyoplankton. ROMS velocity fields are interpolated at $3 \mathrm{~h}$ time steps. A horizontal dispersion factor $\left(1 \times 10^{-9} \mathrm{~m}^{2} \mathrm{~s}^{-3}\right)$ was included following Peliz et al. (2007a). 


\section{Parameters}

Biological parameters used in this study were drawn from the literature. As spawning of Iberian sardines occurs on the continental shelf all along the Iberian coastline, including the southern Portuguese coast (Ré et al. 1990, Cunha et al. 1992, Checkley et al. 2010), fifteen release zones were defined to simulate spawning off the western Iberian coast along the north-south oriented coastline from Galicia to Cabo São Vicente $\left(43.5^{\circ} \mathrm{N}-37.25^{\circ} \mathrm{N}\right)$, and along the east-west oriented Algarve coast in the south $\left(8.85^{\circ} \mathrm{W}-7^{\circ} \mathrm{W}\right)$ (zones 10-24; Fig. 1). All the release zones overlap with recruitment zones and additional recruitment zones were defined for the Cantabrian Coast in the north (zones $1-9 ; 8.85^{\circ} \mathrm{W}-4.65^{\circ} \mathrm{W}$; Carrera and Porteiro 2003), for the southern Iberian coastline (zones $25-27 ; 7^{\circ} \mathrm{W}-5.15^{\circ} \mathrm{W}$; Santos et al. 2001), for the northern African coast (zones $28-30 ; 34.76^{\circ} \mathrm{N}-35.9^{\circ} \mathrm{N}$; Furnestin and Furnestin 1953, FAO 1985), and into the Mediterranean Sea (zones 31-36; 5.35 $\mathrm{W}-3.5^{\circ} \mathrm{W}$; Garcia et al., 1988). Release and recruitment zones are defined based on their bathymetry: nearshore (0$100 \mathrm{~m})$, mid-shelf (100-200 m) and offshelf (200-1000 m). Release and recruitment zones are sequentially numbered from north to south, east to west (Fig. 1). Zones were created to be as equal as possible in terms of the length of coastline $(\sim 165 \mathrm{~km})$, with the exception of the recruitment zones 1-3, which are smaller $(\sim 140 \mathrm{~km})$ due to the geographical boundaries of the ROMS domain $\left(34.75^{\circ} \mathrm{N}\right.$ to $44.98^{\circ} \mathrm{N},-13.64^{\circ} \mathrm{E}$ to $\left.-3.44^{\circ} \mathrm{E}\right)$. A final zone (37) is defined as bathymetry $>1000 \mathrm{~m}$, which is considered offshore. Larval waste is assumed for all individuals that are found offshore at the end of the dispersal period (30 days), as offshore transport is commonly hypothesized to be detrimental for fish larval survival (Parrish et al. 1981, Bakun and Parrish 1982).

Fifty thousand eggs were released simultaneously and randomly over the 15 release areas (Fig. 1) every 10 days, approximating the spawning frequency of S. pilchardus (Bernal et al. 2001). Sardines off the Iberian Peninsula spawn throughout the year, although their 
spawning peak is in the winter (Figueiredo and Santos 1989, Ré et al. 1990, Coombs et al. 2006); therefore eggs were released throughout the year to investigate the effect of seasonal circulation patterns on transport and recruitment. Eggs became larvae after three days (Garrido et al. 2015). Individuals were tracked for 30 days, which represents the duration of the passive larval stage. About this age, sardines have the flexion of the notochord complete, caudal and dorsal fins are fully developed and larvae can swim against horizontal currents (Garrido et al. 2016).

We tested numerous spawning and release parameters for which there is no definitive consensus in the literature (Table 1). We tested the effect of the patchiness of the egg release (1 egg per patch, 10 eggs per patch, or 100 eggs per patch) as in Brochier et al. (2008a). Spawning of S. pilchardus is thought to occur over the continental shelf (Ré et al. 1990, Cunha et al. 1992, Santos et al. 2004, Garrido et al. 2009) and near the ocean floor (Matsuoka and Konishi 1996, Fletcher and Sumner 1999, Dopolo et al. 2005, Ganias and Nunes 2011), though there is no consensus on the spawning depth. Thus, we tested a range of release depths (0-20 m, 20-40 m, 40-60m, 60-80 m, and 80-100 m).

Three scenarios for diel vertical migration (DVM) were tested. The first DVM scenario was taken from Santos et al. (2006) who found that the majority of actively vertically migrating larvae traveled to the neuston layer $(0 \mathrm{~m})$ at night, and the majority of larvae were found at $\sim 25 \mathrm{~m}$ during the day (DVM1). As the depth range of this vertical migration is not great, and is generally within the mixed layer of the region of interest, a second DVM scenario was investigated for the extreme depth ranges of larvae found off the Iberian Peninsula, i.e., $0 \mathrm{~m}$ at night and $100 \mathrm{~m}$ during the day (DVM2; Santos et al. 2006). DVM is primarily driven by larval behavior (i.e., avoidance of predators and harmful UV radiation; Haney 1988, Rhode et al. 2001, Carr et al. 2008) and food availability (Han and Straškraba 2001) as sardines are visual predators and tend to feed during the day (Gliwicz and 
Pijanowska 1988). In the main spawning region off northwestern Iberia, food is concentrated in the upper $25 \mathrm{~m}$. Therefore, we included a food mediated reversal DVM strategy in which sardines feed in the area of highest food concentration during the day $(0 \mathrm{~m})$, and then passively sink to $45 \mathrm{~m}$ during the night (DVM3; as in Olivar et al. 2001). All vertical migration scenarios are implemented at 17 days, which approximates when $S$. pilchardus larvae started diel rhythms of air bladder inflation and directed vertical movements become possible (Ré et al. 1984, Santos et al. 2007).

Table 1: Summary of the parameters tested in the simulations.

\begin{tabular}{|c|c|c|}
\hline Parameters tested & Summary & References \\
\hline Release area & $\begin{array}{l}\text { - Zones 10-24 (Fig. 1) } \\
\text { Bathymetry: onshore }(0-100 \mathrm{~m}) \text {, shelf (100-200 } \\
\mathrm{m}) \text {, offshelf (200-1000 m) - }\end{array}$ & $\begin{array}{l}\text { Ré et al. } 1990 \\
\text { Cunha et al. } 1992 \\
\text { Garrido et al. } 2009 \\
\text { Checkley et al. } 2010\end{array}$ \\
\hline Period & - Climatology of 20 years 1989-2008 - & --- \\
\hline Month & - All months - & --- \\
\hline Frequency & - Every $10 \mathrm{~d}$ at 21:00 - & Bernal et al. 2001 \\
\hline Transport duration & $-30 d-$ & $\begin{array}{l}\text { Ré et al. } 1986 \\
\text { Santos et al. } 2007 \\
\text { Garrido et al. } 2016\end{array}$ \\
\hline Patchiness & $-1,10$, and 100 particles per patch - & Brochier et al. 2008a \\
\hline Release depth & $-0-20 \mathrm{~m}, 20-40 \mathrm{~m}, 40-60 \mathrm{~m}, 60-80 \mathrm{~m}, 80-100 \mathrm{~m}-$ & $\begin{array}{l}\text { Matsuoka and Konishi } 1996 \\
\text { Fletcher and Sumner } 1999 \\
\text { Dopolo et al. } 2005 \\
\text { Ganias and Nunes } 2011\end{array}$ \\
\hline Egg density & - $1.023,1.024,1.025,1.026,1.027,1.028 \mathrm{~g} \mathrm{~cm}^{-3}-$ & Coombs et al. 2004 \\
\hline Diel vertical migration & $\begin{array}{l}\text { - DVM1 - Day: } 25 \mathrm{~m} \text {, Night: } 0 \mathrm{~m} \\
\text { DVM2 - Day: } 100 \mathrm{~m} \text {, Night: } 0 \mathrm{~m} \\
\text { DVM3 - Day: } 0 \mathrm{~m} \text {, Night: } 45 \mathrm{~m} \text { - }\end{array}$ & $\begin{array}{l}\text { Santos et al. } 2006 \\
\text { Olivar et al. } 2001\end{array}$ \\
\hline
\end{tabular}

Finally, different values of egg density were tested to assess the effect of egg buoyancy at the time of the initial release of eggs. Coombs et al. (2004) found that S. pilchardus eggs increase in density from 1.023 to $1.028 \mathrm{~g} \mathrm{~cm}^{-3}$ over the three days of the egg stage. Therefore, we simulated six different egg densities $\left(\rho=1.023,1.024,1.025,1.026,1.027,1.028 \mathrm{~g} \mathrm{~cm}^{-3}\right)$ 
for the three days of the egg stage.

\section{Simulations}

Three simulations were performed which investigated separately the effect of the patchiness of the spawning release (Simulation 1), the vertical migration scenarios (Simulation 2), and the differing egg densities (Simulation 3). For simulations 1 and 3, particles were released within different depth ranges $(0-20 \mathrm{~m}, 20-40 \mathrm{~m}, 40-60 \mathrm{~m}, 60-80 \mathrm{~m}$, and 80-100 m) and were allowed to drift freely after release (i.e., no vertical migration scenario was assigned). For simulations 2 and 3, all 50,000 particles were released randomly within the release zones (i.e., one egg per patch). For simulations 1 and 2, no buoyancy was assigned to the egg stage, defaulting to neutral buoyancy. Though efforts were made to make the release and recruitment zones of equal distance along the coast, the zones vary in volume due to the variability of bathymetry. Therefore, transport and recruitment indices are examined as proportions (0-1) relative to the number of eggs released within each zone. After the 30-day transport duration, larvae were defined as having "recruited" if they were found anywhere in between the coast line and the 1000 m bathymetry line in any of the 36 recruitment areas (Fig. 1), "retained" if they were found in the zone from which they were released, and "dead" if they were found offshore (beyond the $1000 \mathrm{~m}$ bathymetry line; zone 37 ). To identify the important variables determining recruitment and retention for each of the three simulations, Generalized Linear Models (GLM) with a binomial response (one model for recruitment and another model for retention as response variable for each of the three simulations) and a logit link were used. Explanatory variables were patch, depth, month and release zones for simulation 1, diel vertical migration, month and release zone for simulation 2 and buoyancy,

month and release zone for simulation 3. To simplify model interpretation and avoid collinearity, no interactions were considered. Models were selected by backward selection of 
variables based on the Akaike information criteria (AIC). The Wald test was used to assess the importance of each predictor for the models. 


\section{RESULTS}

\section{Simulation 1: Patchiness}

We find that the patchiness of the release has no effect on the retention of virtual larvae and on the recruitment at $\mathrm{p}<0.01$ (Table 2). Retention was higher from the end of the winter and spring but successful recruitment occurred when eggs were released during the peak of the spawning season (October to January; Table 2), which could explained the adaptation of sardines to reproduce in coastal upwelling systems subject to intense offshore transport. Recruitment and retention were higher when eggs were released from deeper than $40 \mathrm{~m}$, indicating that offshore transport is a higher risk for eggs and larvae when they are released closer to the surface (Figs 2a-e). We found that recruitment was highest near the release site (Figs 2a-e), which indicated that there was self-recruitment of larvae in the zone of release. Mortality was lower in northwestern and central Iberian release sites (Figs 2a-e). Highest local retention was observed from the central Iberian coast (zones 16-18; but also 13, 19 and 22; Fig. 3 and Table 2), and the lowest mortality was observed from nearshore release zones but especially from northwestern Portugal (zones 10 and 13; Fig. 3 and Table 2) and Algarve (zone 22; Fig. 3 and Table 2). Mortality was highest from the offshelf release zones (zones 12, 15, 17, 18, 20, 21 and 24; Fig. 3). In general, the eggs released from nearshore zones had the highest recruitment and lower mortality.

We found substantial alongshore transport for the release zones off the Iberian Peninsula. A relatively large proportion of larvae were transported northward into Galicia and the Cantabrian coast (1-9; up to 27\%) from the northern release zones (10-15; Figs 2 and 3). A large proportion of larvae were transported eastward (up to 36\%) from the Algarve nearshore and mid-shelf zones (22-23) into the neighboring shelf zone in the Gulf of Cadiz (zone 25; Fig. 2 and 3). Some larvae from zones 22 and 23 (up to 8\%) even continued eastward into the Mediterranean (Fig. 3). A maximum of $1 \%$ of larvae were found to transport southward into 
northern Africa, and these were released from the offshore zone of the Algarve (zone 24; Fig. 2 and 3$)$.

Table 2: The coefficients and calculated probability (p-value) of each explanatory variable on retention (Ret) and recruitment (Rec) for simulation 1 (Sim 1: patchiness) as derived from a Generalized Linear Model (GLM Binomial).

\begin{tabular}{|c|c|c|c|c|}
\hline \multirow{2}{*}{$\begin{array}{l}\text { Sim } 1 \\
\text { Variable }\end{array}$} & \multicolumn{2}{|c|}{ Recruitment } & \multicolumn{2}{|c|}{ Retention } \\
\hline & Coefficients & $\mathbf{P}$ & Coefficients & $\mathbf{p}$ \\
\hline (Intercept) & $1.69 \mathrm{E}+00$ & $<<0.0001$ & $-2.31 E+00$ & $<<0.0001$ \\
\hline Patch & $-3.52 \mathrm{E}-05$ & 0.012 & $1.16 \mathrm{E}-06$ & 0.920 \\
\hline Depth & $2.89 \mathrm{E}-02$ & $<<0.0001$ & $1.08 \mathrm{E}-02$ & $<<0.0001$ \\
\hline month2 & $-8.36 \mathrm{E}-02$ & $<<0.0001$ & $3.18 \mathrm{E}-01$ & $<<0.0001$ \\
\hline month3 & $-4.88 \mathrm{E}-01$ & $<<0.0001$ & $3.80 \mathrm{E}-01$ & $<<0.0001$ \\
\hline month4 & $-9.89 \mathrm{E}-01$ & $<<0.0001$ & 4.35E-02 & $<<0.0001$ \\
\hline month5 & $-1.13 \mathrm{E}+00$ & $<<0.0001$ & $6.91 \mathrm{E}-03$ & 0.011 \\
\hline month7 & $-2.12 \mathrm{E}+00$ & $<<0.0001$ & $-5.37 \mathrm{E}-01$ & $<<0.0001$ \\
\hline month8 & $-1.52 \mathrm{E}+00$ & $<<0.0001$ & $-3.35 \mathrm{E}-02$ & $<<0.0001$ \\
\hline month9 & $-5.13 \mathrm{E}-01$ & $<<0.0001$ & $1.54 \mathrm{E}-01$ & $<0.0001$ \\
\hline month10 & $6.60 \mathrm{E}-01$ & $<<0.0001$ & $-2.46 \mathrm{E}-01$ & $<<0.0001$ \\
\hline month11 & $4.20 \mathrm{E}-01$ & $<<0.0001$ & $-1.72 \mathrm{E}-01$ & $<<0.0001$ \\
\hline month12 & $2.13 \mathrm{E}-01$ & $<<0.0001$ & $-4.66 \mathrm{E}-01$ & $<<0.0001$ \\
\hline release11 & $-4.42 \mathrm{E}-02$ & $<<0.0001$ & 4.38E-01 & $<<0.0001$ \\
\hline release 12 & $-1.52 \mathrm{E}+00$ & $<<0.0001$ & $-3.43 \mathrm{E}-01$ & $<<0.0001$ \\
\hline release 13 & $5.72 \mathrm{E}-01$ & $<<0.0001$ & $1.28 \mathrm{E}+00$ & $<<0.0001$ \\
\hline release14 & $-6.95 \mathrm{E}-02$ & $<<0.0001$ & $6.10 \mathrm{E}-01$ & $<<0.0001$ \\
\hline release 15 & $-1.01 \mathrm{E}+00$ & $<<0.0001$ & $-2.27 \mathrm{E}-01$ & $<<0.0001$ \\
\hline release16 & $-7.00 \mathrm{E}-01$ & $<<0.0001$ & $8.27 \mathrm{E}-01$ & $<<0.0001$ \\
\hline release 17 & $-6.95 \mathrm{E}-01$ & $<<0.0001$ & $9.44 \mathrm{E}-01$ & $<<0.0001$ \\
\hline release 18 & $-2.05 \mathrm{E}+00$ & $<<0.0001$ & 4.67E-01 & $<<0.0001$ \\
\hline release19 & $-5.98 \mathrm{E}-01$ & $<<0.0001$ & 4.89E-01 & $<<0.0001$ \\
\hline release20 & $-1.11 \mathrm{E}+00$ & $<<0.0001$ & $2.09 \mathrm{E}-01$ & $<<0.0001$ \\
\hline release 21 & $-2.31 \mathrm{E}+00$ & $<<0.0001$ & $1.07 \mathrm{E}+00$ & $<<0.0001$ \\
\hline release 22 & $1.82 \mathrm{E}-01$ & $<<0.0001$ & 4.93E-01 & $<<0.0001$ \\
\hline release 23 & $-9.94 \mathrm{E}-01$ & $<<0.0001$ & $-3.03 \mathrm{E}-01$ & $<<0.0001$ \\
\hline release 24 & $-3.16 \mathrm{E}+00$ & $<0.0001$ & $-1.12 \mathrm{E}-02$ & $<<0.0001$ \\
\hline AIC & 480 & & 378 & \\
\hline
\end{tabular}

There is substantial variability in the seasonality of recruitment and retention between release depths and release zones (Fig. 4). Recruitment and retention peaks switch with release depth, from primarily during autumn, winter and spring at 0-20 $\mathrm{m}$ to primarily during summer at 80 - 
$100 \mathrm{~m}$ (Fig. 4). A closer analysis of the 0-20 m release depth level reveals three different seasonal patterns: 1$)$ the northern release zones (10-15) have two peaks in retention in fall (October to December) and spring (February to May); 2) the central and southwestern Iberian coast zones (16-21) and the nearshore and mid-shelf release zones off the Algarve coast (2223) have one peak in retention in winter/spring; and 3) the offshelf release zone of the Algarve coast (24) has a peak in retention in the summer (Fig. 4). It is noteworthy that the inshore and mid-shelf release zones off the Algarve coast share a similar seasonal signal to the southwestern Iberian coast but not to their offshelf zone.
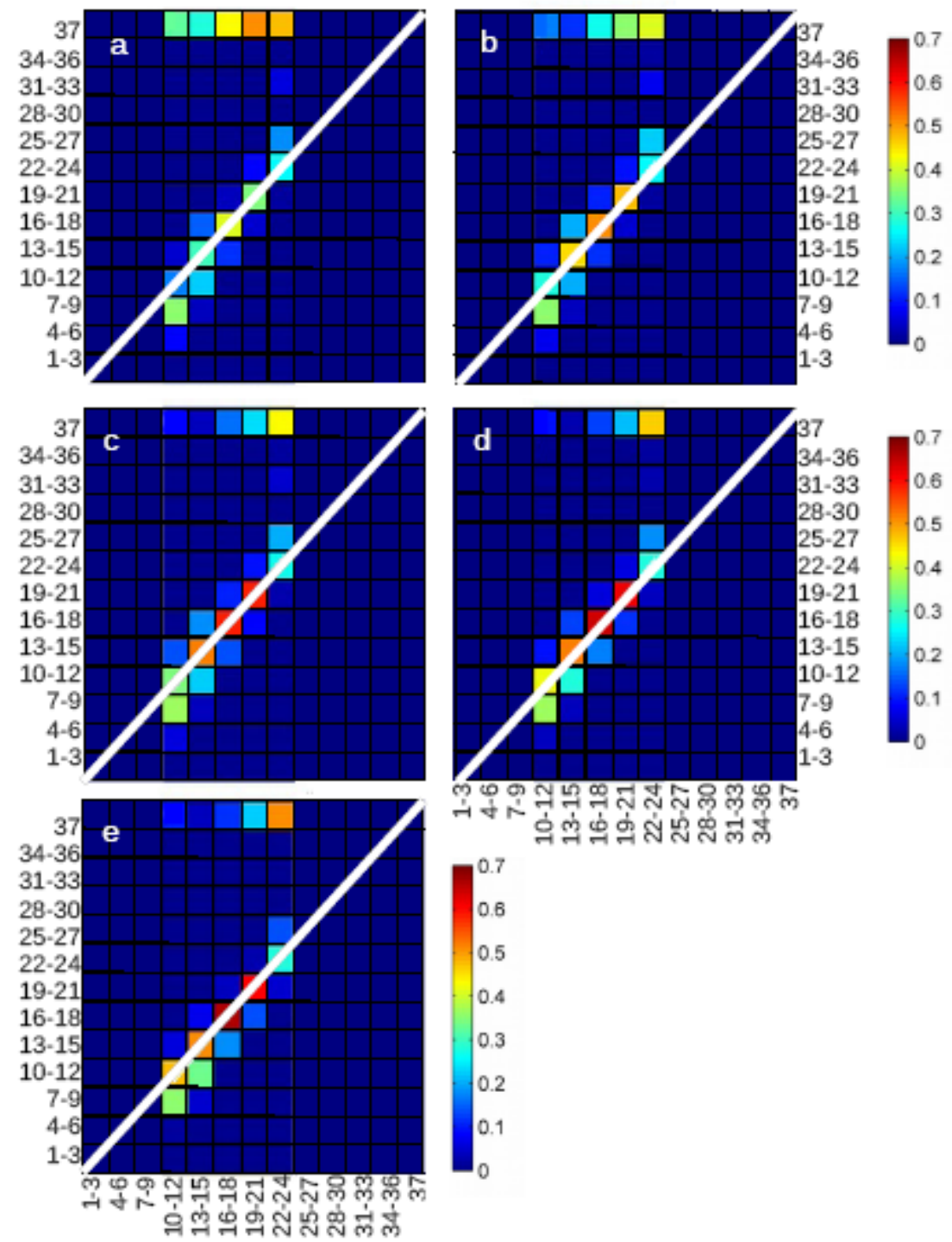

Figure 2. Connectivity matrix averaged over release time for Simulation I with patchiness of one egg per patch for release depths (a) 0-20 m, (b) 20-40 m, (c) 40-60 m, (d) 60-80 m, and (e) 80-100 m. Release zones are aggregated by length of coastline to enhance visibility of the alongshore transport. 
Colors represent the proportion of individuals released from each release zone that were transported to each recruitment zone. Each column sums to one. Zone 37, representing offshore transport, is assumed mortality in this study. The white line represents retention in each release zone.

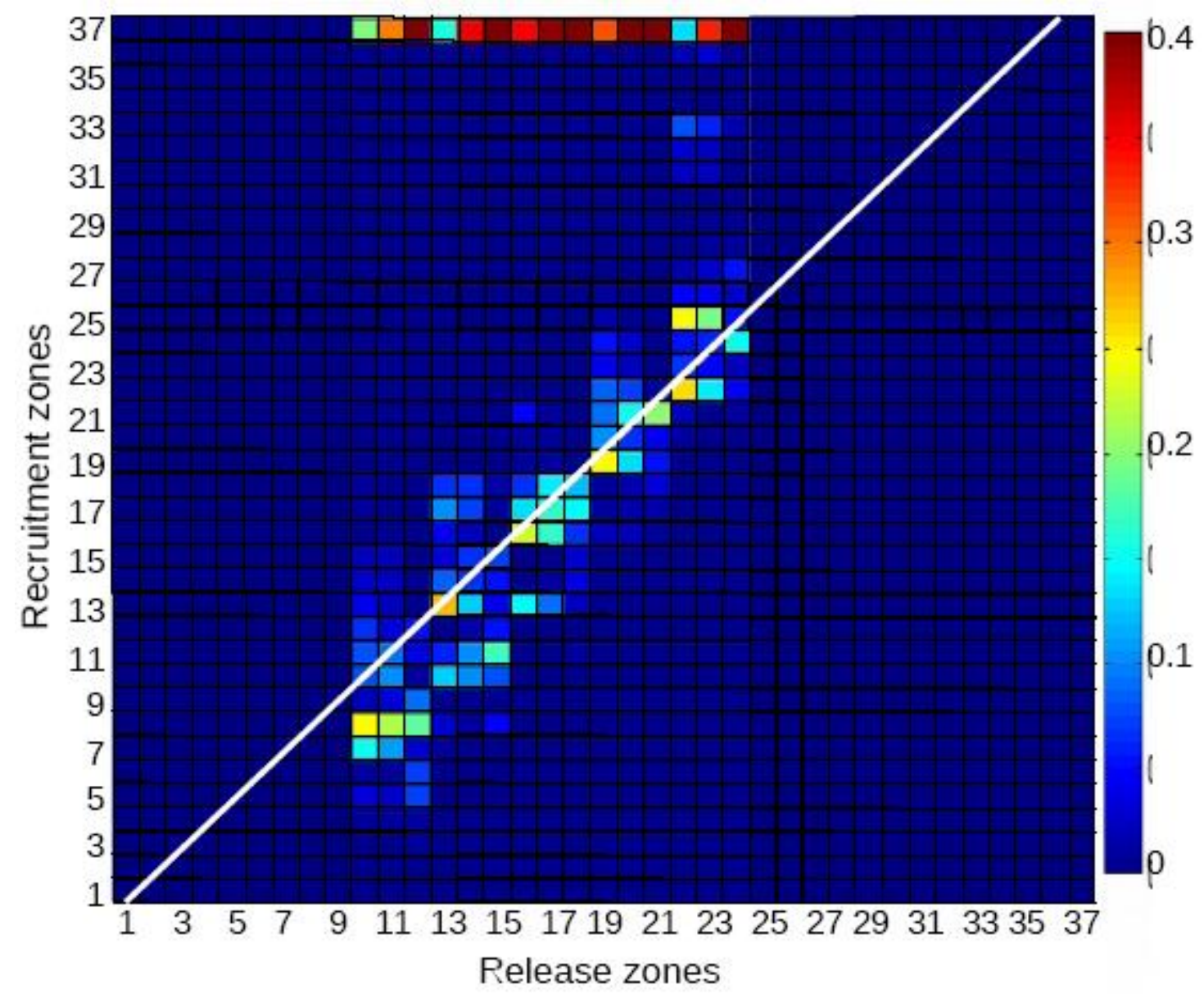

Figure 3. Connectivity matrix averaged over release time for Simulation I with patchiness of one egg per patch for the release depth $0-20 \mathrm{~m}$.

\section{Simulation 2: Vertical migration}

We find that including a DVM strategy significantly increases the mortality of larvae in all release zones (Table 3). DVM1 (Day: $25 \mathrm{~m}$, Night: $0 \mathrm{~m}$ ) and DVM2 (Day: $100 \mathrm{~m}$, Night: 0 $\mathrm{m})$ are essentially the same in terms of recruitment, and DVM3 (Day: $0 \mathrm{~m}$, Night: $45 \mathrm{~m}$ ) has significantly higher mortality than the other two DVM schemes (Fig. 5 and Table 3). As with the previous simulation, we find that both retention and recruitment are higher when eggs are released from deeper depths (Fig. 6 and Table 3). 
Table 3: The coefficients and calculated probability (p-value) of each explanatory variable on retention (Ret) and recruitment (Rec) for simulation 1 (Sim 2: Diel Vertical Migration) as derived from a Generalized Linear Model (GLM Binomial).

\begin{tabular}{|c|c|c|c|c|}
\hline \multirow{2}{*}{$\begin{array}{l}\text { Sim } 2 \\
\text { Variable }\end{array}$} & \multicolumn{2}{|c|}{ Recruitment } & \multicolumn{2}{|c|}{ Retention } \\
\hline & Coefficients & $\mathbf{p}$ & Coefficients & $\mathbf{p}$ \\
\hline (Intercept) & $3.21 \mathrm{E}+00$ & $<<0.001$ & $-1.72 \mathrm{E}+00$ & $<<0.001$ \\
\hline dvm1 & $-6.18 \mathrm{E}-01$ & $<<0.001$ & $-4.64 \mathrm{E}-01$ & $<<0.001$ \\
\hline dvm2 & $-5.34 \mathrm{E}-01$ & $<<0.001$ & $-2.68 \mathrm{E}-01$ & $<<0.001$ \\
\hline dvm3 & $-1.16 \mathrm{E}+00$ & $<0.001$ & $-7.05 \mathrm{E}-01$ & $<0.001$ \\
\hline depth & $1.01 \mathrm{E}-02$ & $<<0.001$ & $3.15 \mathrm{E}-03$ & $<<0.001$ \\
\hline month2 & $-2.65 \mathrm{E}-01$ & $<<0.001$ & $1.74 \mathrm{E}-01$ & $<0.001$ \\
\hline month3 & $-6.85 \mathrm{E}-01$ & $<<0.001$ & $1.22 \mathrm{E}-01$ & $<<0.001$ \\
\hline month4 & $-1.30 \mathrm{E}+00$ & $<<0.001$ & $-3.96 \mathrm{E}-01$ & $<<0.001$ \\
\hline month5 & $-1.80 \mathrm{E}+00$ & $<<0.001$ & $-7.44 \mathrm{E}-01$ & $<<0.001$ \\
\hline month6 & $-2.72 \mathrm{E}+00$ & $<<0.001$ & $-1.70 \mathrm{E}+00$ & $<<0.001$ \\
\hline month7 & $-2.03 E+00$ & $<<0.001$ & $-9.38 \mathrm{E}-01$ & $<0.001$ \\
\hline month8 & $-5.74 \mathrm{E}-01$ & $<<0.001$ & 4.74E-02 & $<<0.001$ \\
\hline month9 & $1.01 \mathrm{E}+00$ & $<<0.001$ & $-2.75 \mathrm{E}-01$ & $<<0.001$ \\
\hline month 10 & $4.58 \mathrm{E}-01$ & $<<0.001$ & $-2.89 \mathrm{E}-01$ & $<<0.001$ \\
\hline month 11 & $1.22 \mathrm{E}-01$ & $<<0.001$ & $-3.60 \mathrm{E}-01$ & $<0.001$ \\
\hline release11 & $-3.81 \mathrm{E}-01$ & $<0.001$ & $3.94 \mathrm{E}-01$ & $<<0.001$ \\
\hline release 12 & $-2.15 E+00$ & $<<0.001$ & $-1.91 \mathrm{E}-01$ & $<0.001$ \\
\hline release 13 & $9.98 \mathrm{E}-01$ & $<<0.001$ & $1.28 \mathrm{E}+00$ & $<<0.001$ \\
\hline release14 & $1.47 \mathrm{E}-01$ & $<<0.001$ & $5.06 \mathrm{E}-01$ & $<<0.001$ \\
\hline release 15 & $-1.04 \mathrm{E}+00$ & $<<0.001$ & $7.79 \mathrm{E}-02$ & $<<0.001$ \\
\hline release 16 & $-8.97 \mathrm{E}-01$ & $<<0.001$ & $1.39 \mathrm{E}+00$ & $<0.001$ \\
\hline release17 & $-1.23 \mathrm{E}+00$ & $<<0.001$ & $1.08 \mathrm{E}+00$ & $<<0.001$ \\
\hline release 18 & $-2.32 E+00$ & $<<0.001$ & 4.83E-01 & $<<0.001$ \\
\hline release19 & $-7.55 \mathrm{E}-01$ & $<<0.001$ & $1.23 \mathrm{E}+00$ & $<0.001$ \\
\hline release 20 & $-1.62 \mathrm{E}+00$ & $<<0.001$ & $-2.30 \mathrm{E}-02$ & $<<0.001$ \\
\hline release 21 & $-2.66 E+00$ & $<<0.001$ & $1.10 \mathrm{E}+00$ & $<0.001$ \\
\hline release22 & $1.48 \mathrm{E}-01$ & $<<0.001$ & $1.06 \mathrm{E}+00$ & $<<0.001$ \\
\hline release 23 & $-8.66 \mathrm{E}-01$ & $<<0.001$ & $-5.18 \mathrm{E}-01$ & $<0.001$ \\
\hline release24 & $-3.01 E+00$ & $<<0.001$ & $4.98 \mathrm{E}-01$ & $<0.001$ \\
\hline AIC & 76072 & & 4776 & \\
\hline
\end{tabular}

The effect of the release depth diminishes from 40-100 m when DVM1 and 2 scenarios are implemented (Fig. 6). Recruitment and retention appear to share the same general patterns for DVM scenarios as for without DVM, though we find lower variability in recruitment with DVM scenarios for depths of $40 \mathrm{~m}$ and greater (Fig. 6). The connectivity matrix reveals that there is less retention and higher mortality when DVM schemes are implemented (Fig. 5). We 

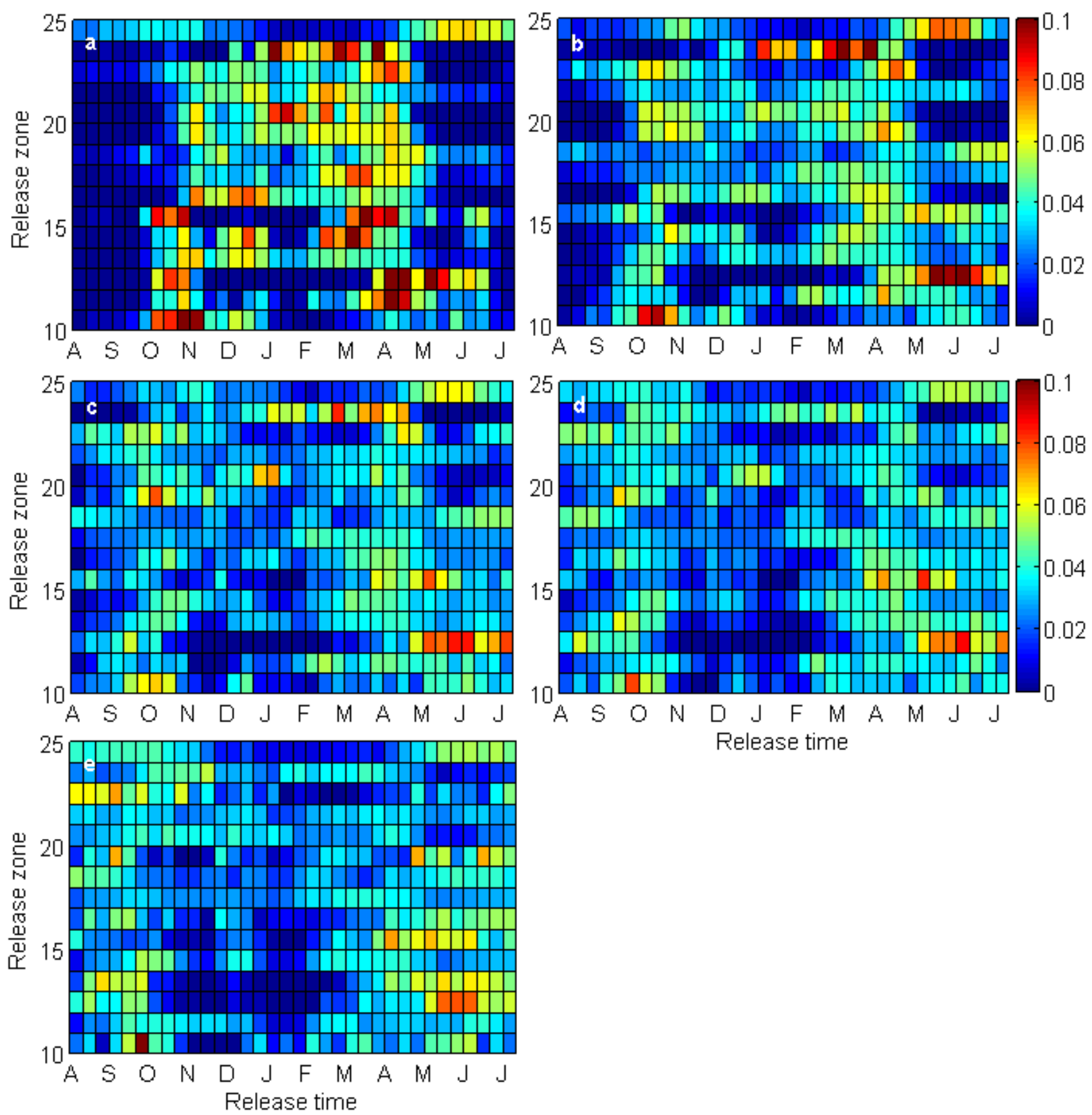

Figure 4. Seasonality of retention for release depths (a) 0-20 m, (b) 20-40 m, (c) 40-60 m, (d) 60-80 $\mathrm{m}$, and (e) 80-100 $\mathrm{m}$ for Simulation 1 with patchiness of one egg per patch. This figure shows the seasonality of retention within each release zone, but gives no information about the relative retention levels between release zones. Colors represent the proportion of individuals that were retained within the release zone (y-axis) for each release time (x-axis) over the total number of simulated larvae that were retained throughout the year. Each row sums to one.

find that a marginally higher percentage of larvae are transported to Galician waters (from release zones 10-12), and a lower percentage to Mediterranean and North African zones 
(from release zones 22-24) with DVM 1 and 2. Slightly less transport and slightly higher mortality is found with DVM3 relative to the other scenarios (Fig. 5). Seasonality is similar for DVM scenarios as for no DVM (not shown).

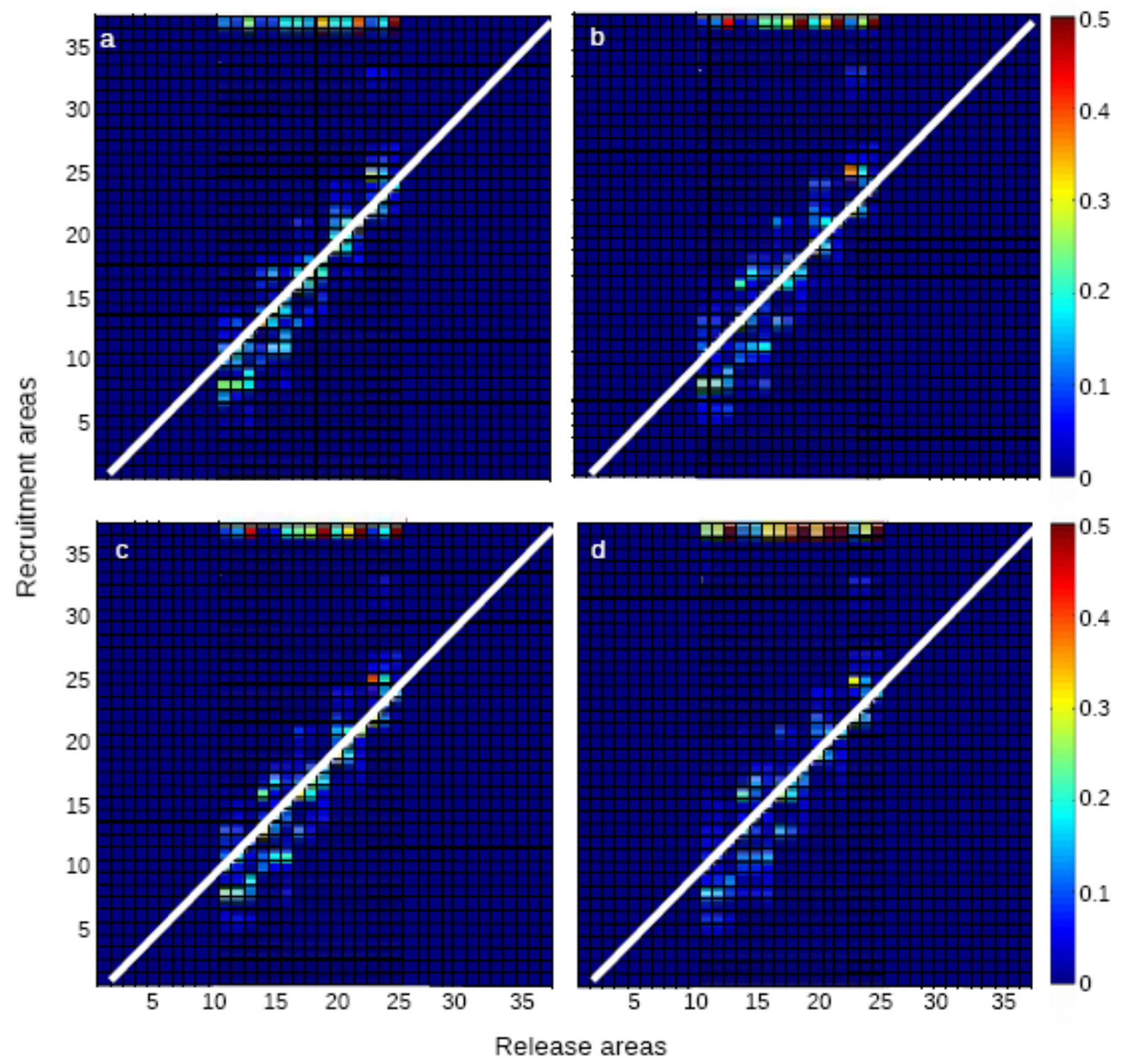

Figure 5. Connectivity matrix averaged over release time and depth for Simulation 2 with a) no Diel Vertical Migration (DVM), b) DVM 1 (Day: 25 m, Night: 0 m), c) DVM 2 (Day: 100 m, Night: 0 m), and d) DVM 3 (Day: 0 m, Night: 45 m). 


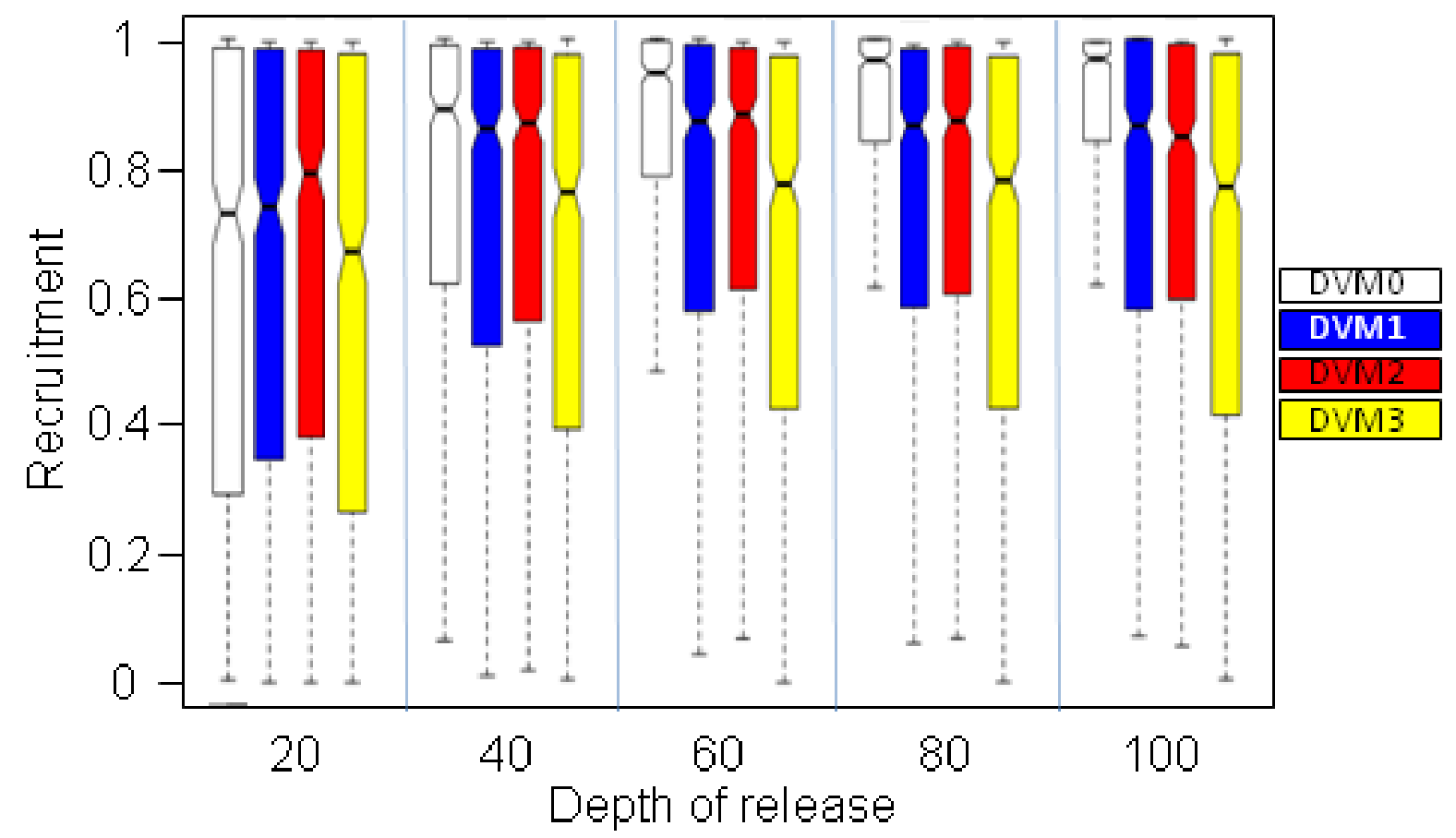

Figure 6. Simulation 2 box and whisker plot of the proportion of simulated larvae that recruited (0-1) at each depth of release for each Diel Vertical Migration (DVM) scenario. The distribution here is summarized by the median (thick horizontal line), the inter-quartile range (IQR; box), and the points up to $1.5 \mathrm{IQR}$ from the median (whiskers). If the notches around the medians do not overlap, this indicates strong evidence that the medians are different (Chambers et al. 1983).

\section{Simulation 3: Egg density}

Recruitment and retention are higher for eggs of higher density (Table 4). There is a distinct division between eggs with low density (1.023-1.025 $\mathrm{g} \mathrm{cm}^{-3}$ ) that have relatively low retention and recruitment and high density eggs $\left(1.026-1.028 \mathrm{~g} \mathrm{~cm}^{-3}\right)$ that have relatively high retention and recruitment (Fig. 7). Less dense eggs have higher mortality and higher alongshore transport (Figs 8a-c) as they float quickly to the surface and are swept offshore or alongshore in the surface layer. More dense eggs are either neutrally buoyant or sink into slower moving deeper waters and, thus, have lower mortality and do not disperse as far (Figs 8e, f). We again find that larvae have higher mortality when they are released from shallower depths, though release depth has little effect on low density eggs. 
Table 4: The coefficients and calculated probability ( $p$-value) of each explanatory variable on recruitment and retention for simulation 3 (Sim 3: Buoyancy) as derived from a Generalized Linear Model (GLM Binomial).

\begin{tabular}{|c|c|c|c|c|}
\hline \multirow{2}{*}{$\begin{array}{l}\text { Sim } 3 \\
\text { Variable }\end{array}$} & \multicolumn{2}{|c|}{ Recruitment } & \multicolumn{2}{|c|}{ Retention } \\
\hline & Coefficients & $\mathbf{P}$ & Coefficients & $\mathbf{P}$ \\
\hline (Intercept) & $1.48 \mathrm{E}+01$ & $<<0.001$ & $2.23 \mathrm{E}+00$ & $<<0.001$ \\
\hline buoyancy & $-1.27 \mathrm{E}+01$ & $<<0.001$ & $-4.29 \mathrm{E}+00$ & $<0.001$ \\
\hline depth & $6.28 \mathrm{E}-03$ & $<<0.001$ & $2.84 \mathrm{E}-03$ & $<0.001$ \\
\hline month2 & $-1.21 \mathrm{E}-01$ & $<<0.001$ & $1.31 \mathrm{E}-01$ & $<0.001$ \\
\hline month3 & $-6.41 \mathrm{E}-01$ & $<<0.001$ & $1.23 \mathrm{E}-01$ & $<<0.001$ \\
\hline month4 & $-1.00 \mathrm{E}+00$ & $<<0.001$ & $-3.39 \mathrm{E}-01$ & $<<0.001$ \\
\hline month5 & $-1.25 \mathrm{E}+00$ & $<<0.001$ & $-4.08 \mathrm{E}-01$ & $<<0.001$ \\
\hline month7 & $-2.12 \mathrm{E}+00$ & $<0.001$ & $-7.82 \mathrm{E}-01$ & $<<0.001$ \\
\hline month8 & $-1.62 \mathrm{E}+00$ & $<0.001$ & $-3.53 \mathrm{E}-01$ & $<0.001$ \\
\hline month9 & $-4.50 \mathrm{E}-01$ & $<0.001$ & $1.16 \mathrm{E}-02$ & $<0.001$ \\
\hline month10 & $1.15 \mathrm{E}+00$ & $<<0.001$ & $-3.62 \mathrm{E}-02$ & $<0.001$ \\
\hline month 11 & 7.47E-01 & $<<0.001$ & $-1.37 \mathrm{E}-01$ & $<0.001$ \\
\hline month12 & 4.89E-01 & $<0.001$ & $-3.17 \mathrm{E}-01$ & $<<0.001$ \\
\hline release11 & $-3.38 \mathrm{E}-02$ & $<<0.001$ & 4.67E-01 & $<0.001$ \\
\hline release 12 & $-1.16 \mathrm{E}+00$ & $<<0.001$ & $-6.83 \mathrm{E}-02$ & $<0.001$ \\
\hline release13 & 7.72E-01 & $<0.001$ & $1.12 \mathrm{E}+00$ & $<<0.001$ \\
\hline release14 & $3.45 \mathrm{E}-01$ & $<<0.001$ & $5.97 \mathrm{E}-01$ & $<0.001$ \\
\hline release 15 & $-2.65 \mathrm{E}-01$ & $<0.001$ & $-3.14 \mathrm{E}-03$ & 0.202 \\
\hline release16 & $-2.41 \mathrm{E}-01$ & $<<0.001$ & $1.11 \mathrm{E}+00$ & $<0.001$ \\
\hline release 17 & $-4.82 \mathrm{E}-01$ & $<<0.001$ & $1.11 \mathrm{E}+00$ & $<0.001$ \\
\hline release18 & $-1.31 \mathrm{E}+00$ & $<<0.001$ & 7.03E-01 & $<0.001$ \\
\hline release19 & $-4.20 \mathrm{E}-01$ & $<0.001$ & $8.89 \mathrm{E}-01$ & $<0.001$ \\
\hline release20 & $-8.89 \mathrm{E}-01$ & $<<0.001$ & 4.13E-01 & $<0.001$ \\
\hline release21 & $-1.74 \mathrm{E}+00$ & $<0.001$ & $1.16 \mathrm{E}+00$ & $<0.001$ \\
\hline release 22 & $2.14 \mathrm{E}-01$ & $<<0.001$ & $1.13 \mathrm{E}+00$ & $<0.001$ \\
\hline release 23 & $-4.87 \mathrm{E}-01$ & $<<0.001$ & $-3.16 \mathrm{E}-02$ & $<0.001$ \\
\hline release 24 & $-2.27 \mathrm{E}+00$ & $<<0.001$ & 4.56E-01 & $<0.001$ \\
\hline AIC & 19345 & & 1028 & \\
\hline
\end{tabular}

Recruitment and retention of larvae with low to medium egg densities (1.023-1.026 g $\mathrm{cm}^{-3}$ ) have similar seasonal patterns (Figs 9a-d) as those that are released from 0-20 m depth for previous simulations (e.g., Fig. 4a). Offshelf of the Algarve (zone 24) shows an opposite seasonal signal to the majority of the zones, with higher retention in the summer period and lower in the winter. This signal is strong for particles of all densities, including those with 
higher densities (Figs 9a-f). Recruitment becomes much more dispersed throughout the year for egg densities of 1.027 and $1.028 \mathrm{~g} \mathrm{~cm}^{-3}$ (Figs 9e, f). Eggs of these densities settle at depths between 50-85 m (Fig. 10), and may be transported in weak undercurrents. A seasonal signal is evident in the depth to which larvae with heavier densities at the egg stage recruit: these are found at deeper depths in September to January $(70$ to $85 \mathrm{~m}$ ), and shallower depths for the rest of the year (50-60 m) (Fig. 10).

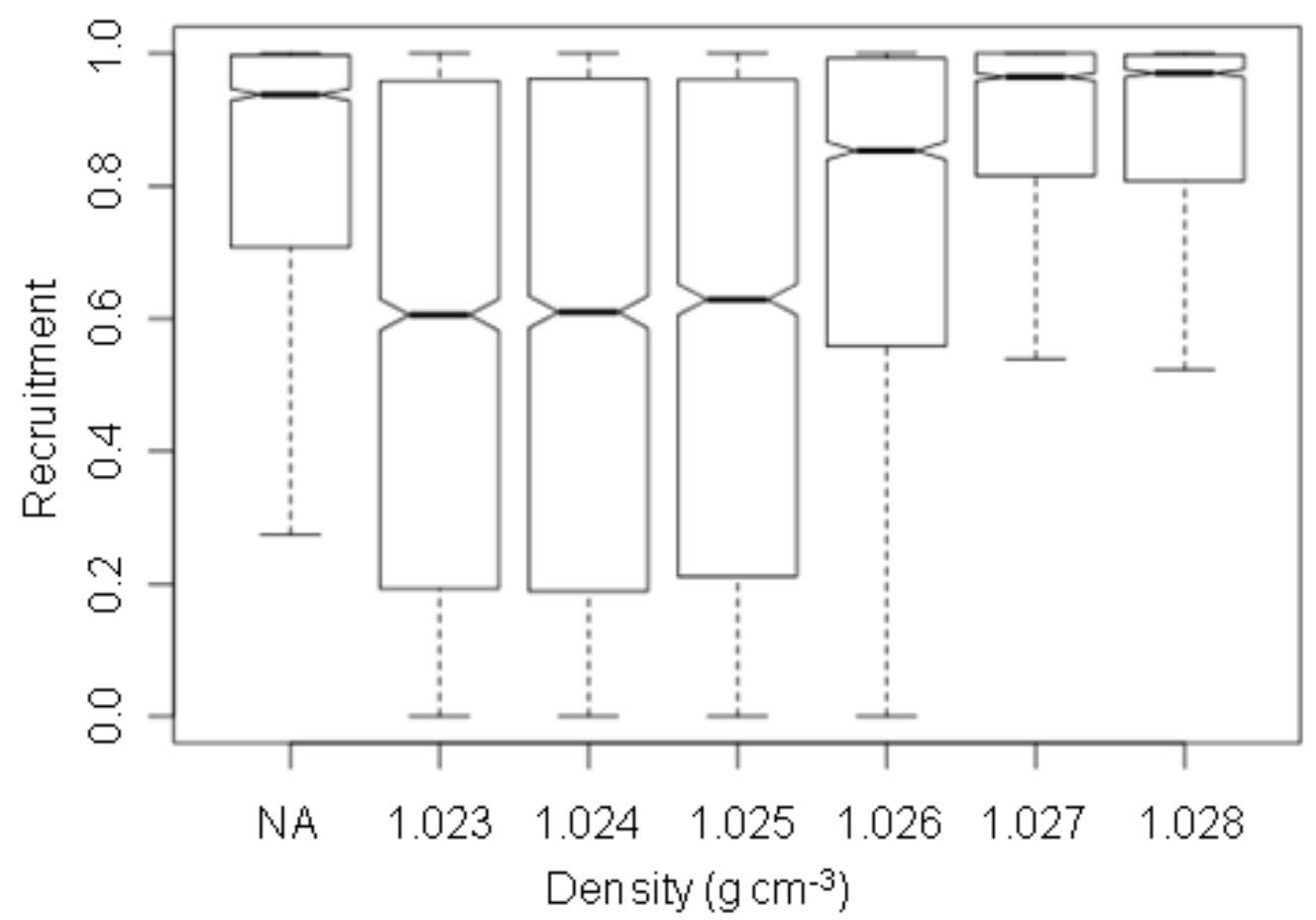

Figure 7. Box and whisker plot of Simulation 3 recruitment (0-1) for varying egg densities (1.023$1.028 \mathrm{~g} \mathrm{~cm}^{-3}$ ). NA represents recruitment for particles with no egg density assigned. 

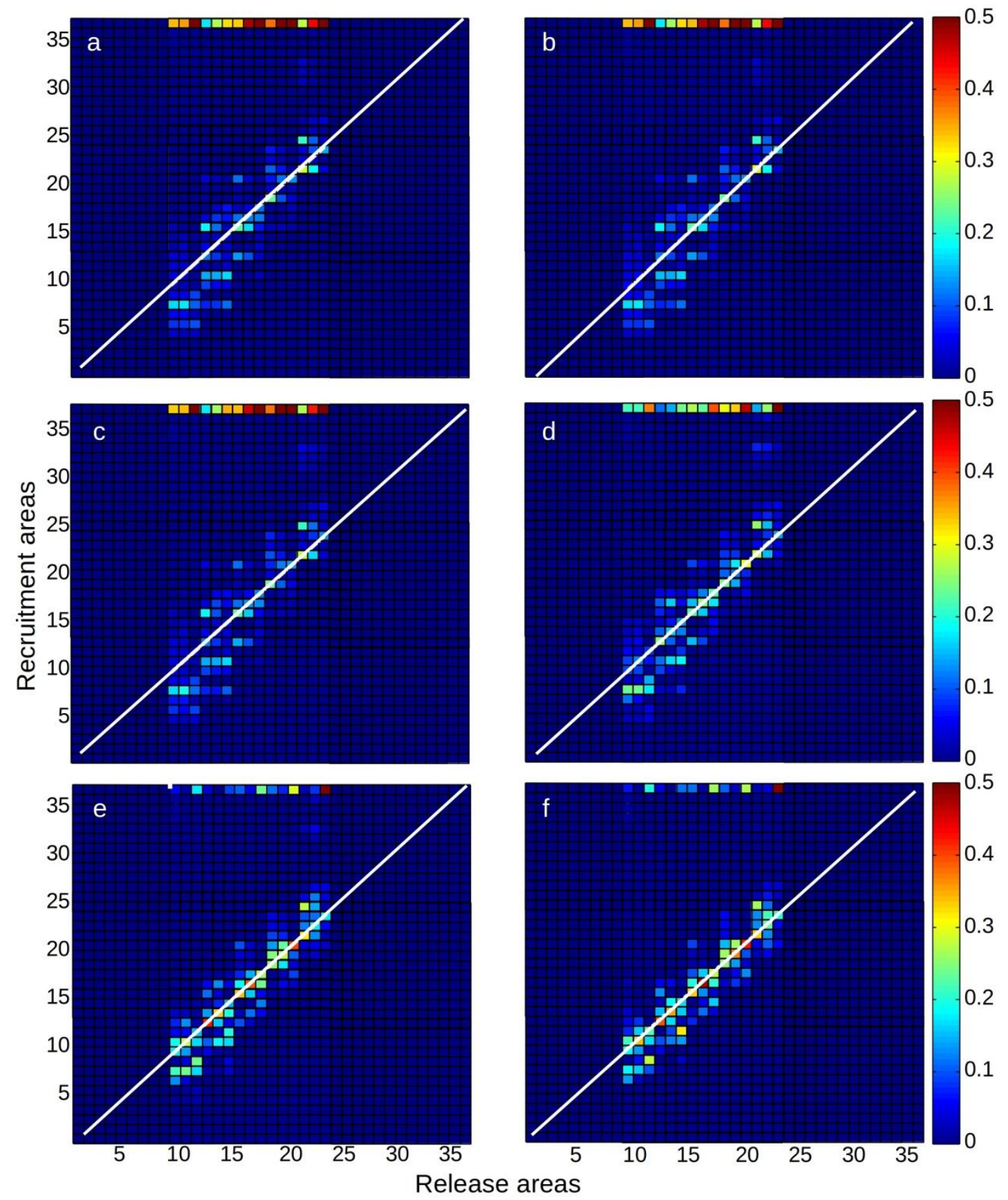

Figure 8. Connectivity matrix of Simulation 3 for particles with egg densities of a) $1.023 \mathrm{~g} \mathrm{~cm}^{-3}, \mathrm{~b}$ ) $1.024 \mathrm{~g} \mathrm{~cm}^{-3}$, c) $1.025 \mathrm{~g} \mathrm{~cm}^{-3}$, d) $1.026 \mathrm{~g} \mathrm{~cm}^{-3}$, e) $1.027 \mathrm{~g} \mathrm{~cm}^{-3}$, and f) $1.028 \mathrm{~kg} \mathrm{~m}^{-3}$. 

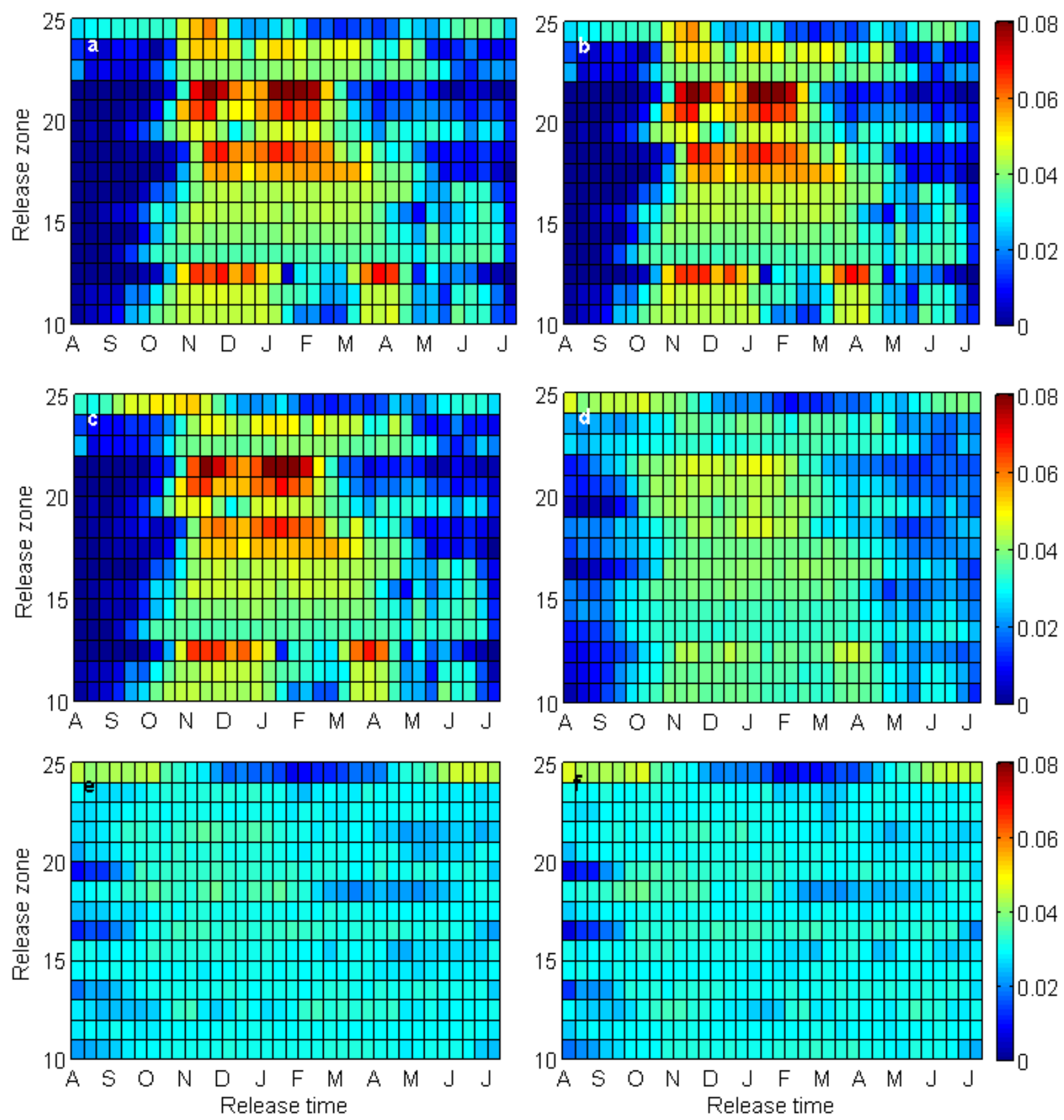

Figure 9. Seasonality of recruitment for Simulation 3 for particles with egg densities of a) $1.023 \mathrm{~g} \mathrm{~cm}^{-}$ , b) $1.024 \mathrm{~g} \mathrm{~cm}^{-3}$, c) $1.025 \mathrm{~g} \mathrm{~cm}^{-3}$, d) $1.026 \mathrm{~g} \mathrm{~cm}^{-3}$, e) $1.027 \mathrm{~g} \mathrm{~cm}^{-3}$, and f) $1.028 \mathrm{~g} \mathrm{~cm}^{-3}$. 


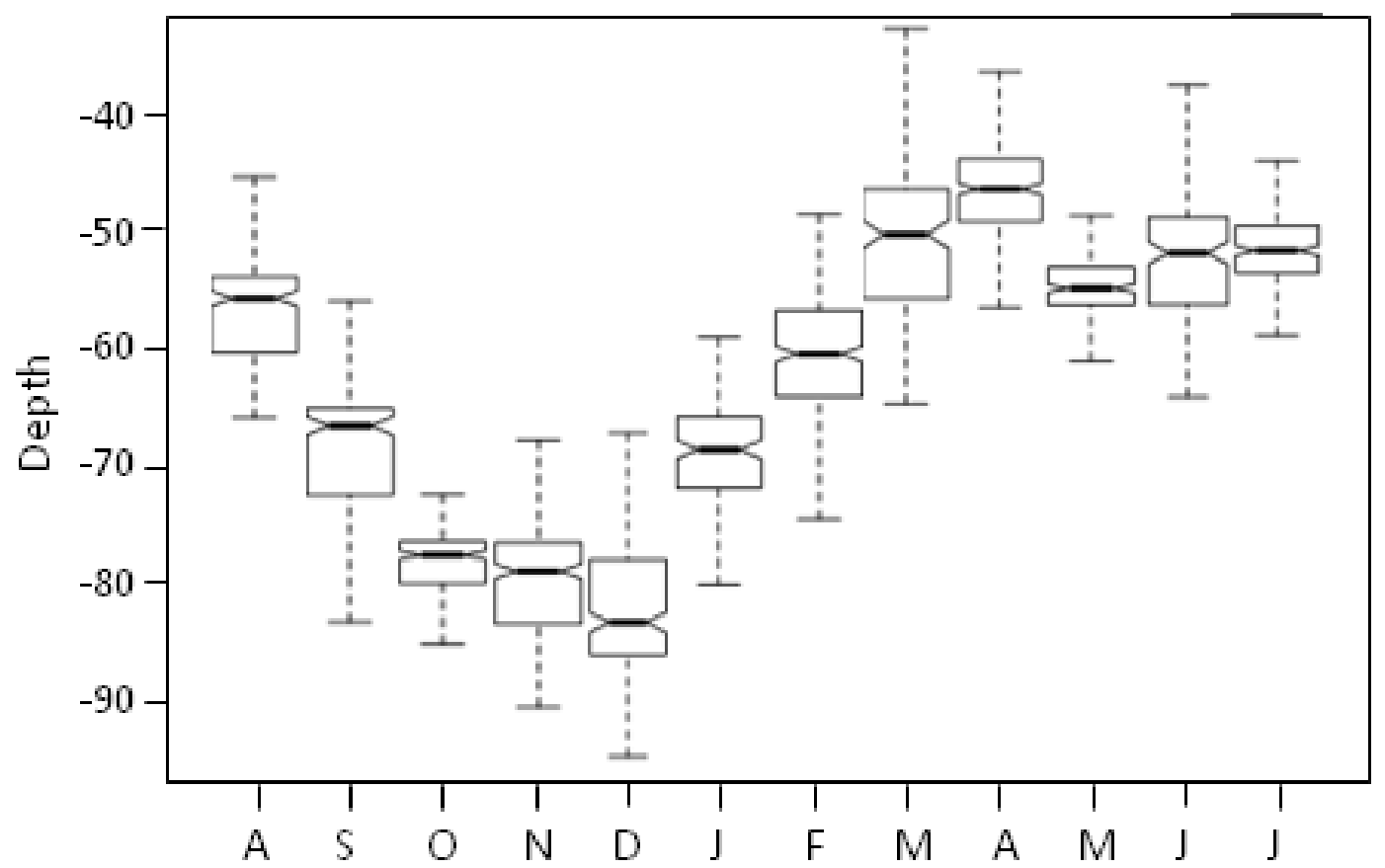

Figure 10. Box and whisker plot of Simulation 3 for the seasonal variation of the median depth at which larvae were found by the end of the 30-day larval duration with an egg density of $1.028 \mathrm{~g} \mathrm{~cm}^{-3}$. 


\section{DISCUSSION}

We developed a transport-dispersal model, which runs over a (canonically) averaged year computed from outputs of a 20 -year high resolution fully realistic ocean model simulation. The objective was to study the main seasonal patterns of transport, retention, and recruitment of larval sardine off the western Iberian Peninsula. Overall, these simulations confirm what is known about the timing and location of sardine spawning off Iberia. This indicates that the model performs well in representing a climatology of the reproductive strategies of the species. This, in turn, confirms that these species are deeply influenced by their physical environment. We find that retention and recruitment of simulated larvae is very high along the western Iberian coastline, especially during the spawning season (in October-March up to 90\%), in relation to other upwelling regions (e.g., sardines in the California Current; Bakun 1996, Humboldt Current; Brochier et al. 2008a). Brochier et al. (2008b) simulations in NW Africa (southern Canary Current Upwelling System) indicate that larval sardine retention is of the order of $40-65 \%$ during December-January. In the Humboldt Current Upwelling System, larval anchovy retention is only 20-54\% from October to June (Brochier et al. 2008a, Parada et al. 2012). In the Benguela Current Upwelling System the percentage of retention of Sardinops sagax eggs and larvae are $24-48 \%$ in South Africa Agulhas Bank spawning grounds and $13-52 \%$ in the west coast spawning areas (Miller et al 2006). The results of the simulations by Garcia-Garcia et al. (2016) in the northwest Iberian coast from November 2006 to February 2007 also demonstrated that there was an important larval retention ( 70\% on average but could be up to $80 \%$ ) during that time. As expected, retention and recruitment are higher the closer inshore the eggs are released. We find the highest retention and recruitment during winter when sardines are known to spawn along this coast (Figueiredo and Santos 1989; Ré et al. 1990, Coombs et al. 2006). We find seasonal variability in recruitment peaks, which varies with cross-shelf transport (Fig. 11). In addition, local retention is high in 
relation to transport to neighboring regions, in accordance with previous studies (Silva et al. 2006; Oliveira and Stratoudakis 2008, Garcia-Garcia et al. 2016). We find similar results to other particle dispersal studies in terms of biological parameters, in that DVM scenarios and the density of the egg stage significantly affect recruitment variability (ANOVA; $p<0.001$, Table 2; e.g., Watanabe et al. 1996, Stenevik et al. 2003), but the influence of the patchiness of particle release is nil (Table 2; e.g., Brochier et al. 2008a). Finally, we find substantial transport northward into Galicia, and low levels of transport southward into Northern Africa and eastward into the Mediterranean, which both concurs and contradicts, respectively, the findings of previous studies (Fage 1920, Parrish et al. 1989, Silva 2003, Chlaida et al. 2006, Chlaida et al. 2009, Baibai et al. 2012). Furthermore, the high proportion of local retention and low but consistent alongshore transport supports the idea of a series of metapopulations along this coast (Carrera and Porteiro 2003, Silva et al. 2006).

\section{Retention}

Our results indicate that the western Iberian Peninsula is a suitable habitat for sardine spawning success in that retention is high and offshore wastage is low, especially along the central coast (zones 13-15 and 16-18). Productivity along the coast is relatively high due to summer upwelling and the runoff of several rivers (Santos et al. 2007, Garrido et al. 2008). The climatological mean circulation in these regions favors retention (Arístegui et al. 2009), especially in the winter when there is low offshore transport (Fig. 11). Retention in this region is aided by interactions between the Iberian Poleward Current and the Western Iberian Buoyant Plume. This feature is fed by river runoff and is hypothesized to provide a nutrientrich environment for larvae (Santos et al. 2004). It is present year-round, but is largest in the winter during the sardine spawning period (Arístegui et al. 2009). Furthermore, the main spawning region has moderate cross-shelf transport, which is generally onshore during the 
winter (spawning period) and generally offshore in the summer, likely related to moderate upwelling conditions (Fig. 11). Survival of the larvae of small pelagic species is often related to moderate environmental conditions (i.e., the Optimal Environmental Window; Cury and Roy, 1989; and Lasker windows; Lasker, 1981). In upwelling regions, this translates to moderate wind stress that leads to productivity that is high enough to encourage feeding success, but not so strong as to lead to high levels of turbulence and offshore advection (Cury and Roy, 1989).

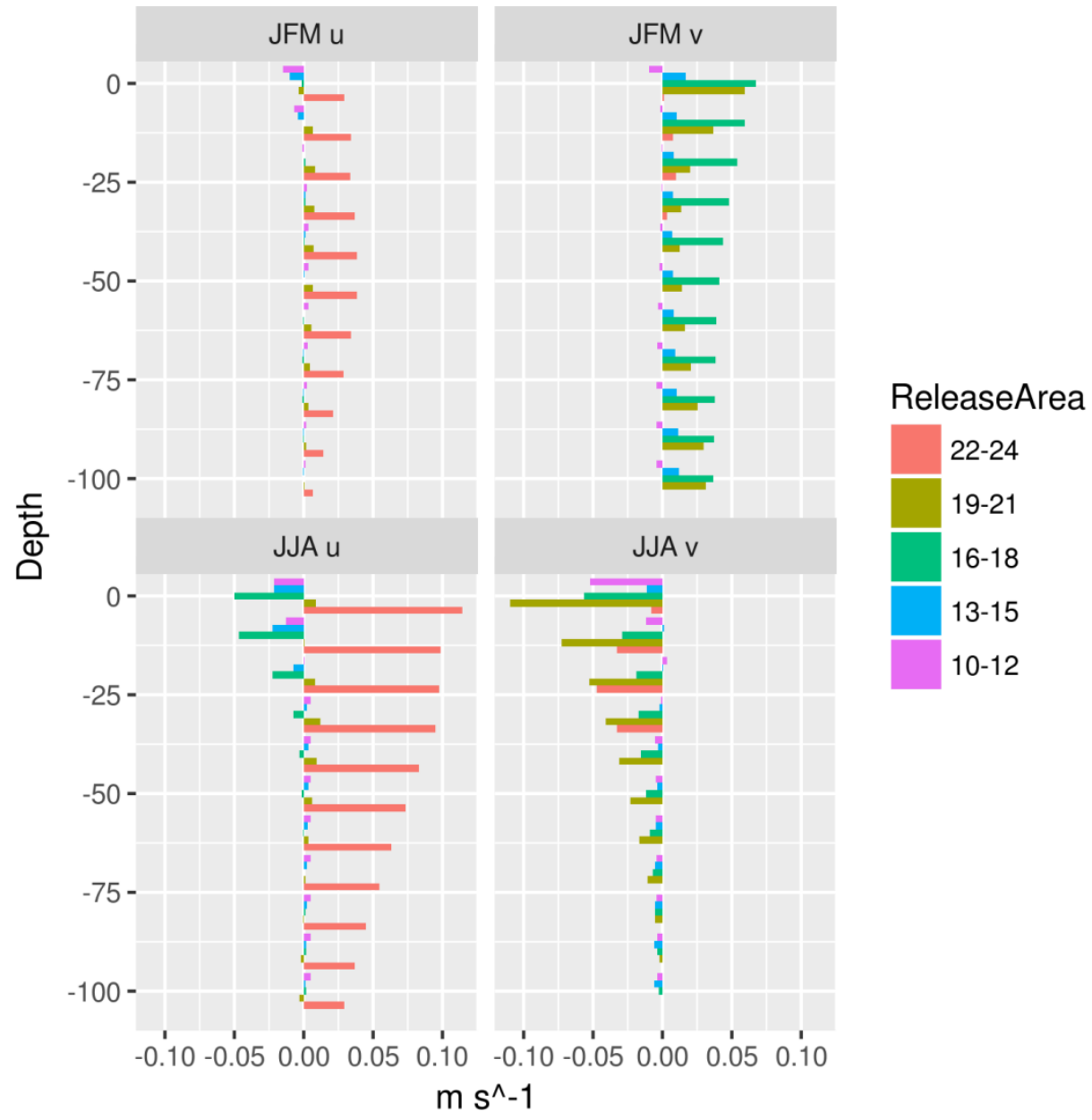

Figure 11. The cross- and alongshore flow $\left(\mathrm{m} \mathrm{s}^{-1}\right)$ in the top $100 \mathrm{~m}$ and within the $200 \mathrm{~m}$ isobath, grouped by release areas during a), b) winter (January-March), and during c), d) summer (JuneAugust). Note that release areas 10-21 are along the north-south oriented coastline; thus, u represents cross-shore flow and v represents alongshore flow. Release areas 22-24 are along the east-west oriented coastline, thus, $\mathrm{u}$ represents alongshore flow, and $\mathrm{v}$ represents cross-shore flow. Negative values of $\mathrm{u}$ means that the flow is westward and of $\mathrm{v}$ that the flow is southward. 


\section{Transport and connectivity}

In addition to retention being high, we find that mean transport of larvae between neighboring regions is generally low $(\sim 5 \%)$, concurring with other studies of larval dispersal performed for this coast (e.g., Oliveira and Stratoudakis 2008, Garcia-Garcia et al 2016). Our results indicate a substantial level of connectivity due to alongshore transport between northwest Iberian spawning areas and recruitment zones to the north (i.e., Galicia and the Cantabrian coast), and low-level transport to the south (i.e., Morocco) and east (i.e., the Mediterranean). Alongshore transport is greater than cross-shelf transport at all depths, especially in winter (Fig. 11). Alongshore currents favor northward transport in the winter spawning period (Fig. 11b), which is especially relevant for the northern release zones (1015; Fig. 3) whose ichthyoplankton disperse northward into Cantabrian waters up to $27 \%$ of the time. Garcia-Garcia et al. (2016) suggest lower values (<7\%) transported to the Cantabrian sea from November to February but their study is limited to the winter period of 2006-2007. Thus, special conditions could have occurred in that limited period of time in contrast to our climatological year. The majority of these larvae originate from offshelf zones, indicating that the northward transport may be due to the Iberian Poleward Current, which is a poleward shelf/slope current that has been identified as far south as Cabo São Vicente and north to Spain and southwest France (Frouin et al. 1990, Haynes and Barton 1990, GarciaSoto et al. 2002) and by a transport mechanism similar to the one propose by Santos et al. /2004).

For the southern release zones, we generally find up to only $1 \%$ of larvae that transport into Northern Africa, in contrast to Oliveira and Stratoudakis (2008) who find up to $50 \%$ transportation success. This massive difference may well be a reflection of several differences in the inputs and methodology between the two studies. Firstly, Oliveira and Stratoudakis (2008) investigate larval dispersal at a different temporal scale than the current 
study (i.e., event-scale versus climatology). Also, it should be noted that altimetry has some known limitations related to the large uncertainty in near-shore areas where sardines spawn combined with the lack of the vertical structure of ocean currents. Finally, there may be an effect due to the biological simplification of larvae to passive particles as used in their study. The cross-shelf currents from the release zones off the Algarve (zones 22-24) indicate that there are strong southward currents during the summer months (Fig. 11d). At a climatological scale, the majority of larvae in this cross-shelf flow may be lost offshore, but there could be a few events of highly successful transport to northern Africa.

A large proportion of larvae from the shelf zones off the Algarve (zones 22 and 23) transport and recruit into the neighboring zone to the east in the Gulf of Cadiz (up to 36\%). This was also observed for larval stages of two species of ghost shrimps (Upogebia pusilla and $U$. deltaura) in the same zone (Pires et al. 2013). Furthermore, this area is relatively sheltered from upwelling winds and circulation is generally retentive (Arístegui et al. 2009). We find up to a further $8 \%$ of larvae that originate from Algarve (zones 22 and 23) transport into the Mediterranean, which contradicts the general belief that the Mediterranean sardines are isolated from Atlantic sardines due to the Strait of Gibraltar (Chlaida et al. 2006, Gonzalez and Zardoya 2007). This dispersal of larvae corresponds with strong eastward transport of the surface layer from the southern release zones, especially in summer (Fig. 11c), and is concurrent with the Gulf of Cadiz slope current (Fig. 1; Peliz et al. 2009).

The results of our study indicate that there is some level of connectivity between the Atlantic-Iberian, North African, and Mediterranean sardine populations. These findings could indicate that sardines along the Iberian Peninsula exist as a series of interacting, but spatiallyseparated subpopulations (i.e., metapopulations; Carrera and Porteiro 2003, Silva et al. 2006). Morphometric analyses show that there is only shallow genetic differentiation and geographic variability of phenotypic characteristics of Atlantic-Iberian sardine subpopulations, indicative 
of geographic isolation by distance (Gonzalez and Zardoya 2007; Laurent et al. 2007). The low-level connectivity that we found in simulations using climatological mean currents could potentially maintain sufficient genetic flow between Iberian subpopulations to sustain demographic connectivity (Kritzer and Sale 2004, Silva et al. 2009).

\section{Mortality}

We find that mortality (offshore transport) is higher in the offshelf zones than inshore and mid-shelf zones due to the closer proximity to the open ocean. Mortality is also high from the southern release zones, consistent with the regions of dispersion found by Arístegui et al. (2009), and is due to the consistent mesoscale activity to the southwest of Lisbon in zones 19, 20, 21, and 24 (e.g., Peliz et al. 2004, Arístegui et al. 2009) that is observed in the ROMS model, which sweeps larvae offshore. The release zone offshelf of the Algarve (zone 24) consistently shows the highest mortality, which may also be due to the influence of the Atlantic Inflow that directs water in the top $300 \mathrm{~m}$ to the southeast towards the Strait of Gilbraltar (Stevenson 1977, Ambar and Howe 1979, Nelson et al. 1999) and offshore of the $1000 \mathrm{~m}$ isobath. Larvae transported to the open ocean are far less likely to encounter sufficient food resources to enable their survival untill metamorphosis (Parrish et al. 1981, Bakun and Parrish 1982, Oliveira and Stratadoukis 2008). Thus, individuals that spawn in the southern, offshelf zones are less likely to produce successful recruits than individuals that spawn in higher-retention areas on the central and northern coast.

Similarly, we find that eggs released closer to the surface have higher mortality due to the increased likelihood of being swept offshore in the cross-shelf flow. We find that seasonality is highly variable between release depths and release zones. Eggs released from the top $20 \mathrm{~m}$ show peaks in recruitment and retention when there is low surface transport due to upwelling (Figs 11a, d). This occurs in winter for most release zones, and summer for the 
zones off the Algarve (Fig. 11, Arístegui et al. 2009). Eggs released from > $40 \mathrm{~m}$ show an opposite signal. The change in the seasonality with depth is a common characteristic of upwelling systems (Penven et al. 2005, Brochier et al. 2008a) and is due to the effects of Ekman transport, whereby upwelling events create offshore transport in the surface zone $(<$ $20 \mathrm{~m}$ ), which translates to onshore transport at depth (Pond and Pickard 1983; e.g., Figs 11a, c).

\section{Patchiness}

Similar to other larval dispersal studies (e.g., Brochier et al. 2008a), we find that the patchiness of particle distribution is not a significant contributor to particle transport. This is likely due to the temporal and/or spatial scale of our study, i.e., the effects of mesoscale features have been smoothed in the climatology, or the spatial scale of the ROMS model (2.3 $\mathrm{km})$ may be larger than the scale at which the variability of larval patchiness is significant.

\section{Diel Vertical Migration}

Interestingly, we find that the DVM strategies observed for sardine subpopulations off Iberia (i.e., DVM1 and DVM2) have little effect on the retention and recruitment but to slightly increase the offshore transport of larvae. However, Santos et al. (2004) and Garrido et al. (2009) observed that in the northwestern Iberian shelf almost all fish larvae (e.g., sardines) are retained inside the Western Iberian Buoyant Plume (WIBP) in the upper $40 \mathrm{~m}$, and Santos et al. (2004) proposed a retention mechanism by the interaction between the Western Iberian Buoyant Plume and the Iberian Poleward Current. However, we did not investigate the degree to which these features interact with DVM behaviors to influence retention and recruitment of larvae, because riverine flow fields incorporated in the ROMS simulation are climatological. 
All DVM scenarios increase recruitment variability, which is counterintuitive as it is generally assumed that passive larvae will experience a wider environmental range than larvae subjected to enforced vertical distribution. However, the higher mortality of these DVM scenarios may be because larvae are consistently in the neuston layer $(0 \mathrm{~m})$ where wind effects and offshore transport are high. Offshore transport experienced by individuals near the surface at night is not compensated by the subsurface onshore flow where individuals migrate during the day. This rapid, offshore surface transport can lead larvae to experience high environmental variability, e.g., alongshore currents of variable strengths, which may also explain the enhanced alongshore transport of DVM1 and DVM2, in accordance with the transport mechanism proposed by Santos et al. (2004).

DVM2 is likely more successful for recruitment and retention than DVM1 as there is less time spent in the upper $20 \mathrm{~m}$, where offshore transport is highest (Fig. 11), and this is also in agreement of the vertical distribution of larvae of fish species, including sardine, in the region (Santos et al 2006, Garrido et al. 2009). In fact, the WIBP could extend deeper as 80 m (e.g., Santos et al., 2004).

DVM strategies are mainly driven by transport patterns, UV or predator avoidance (Haney 1988, Rhode et al. 2001, Carr et al. 2008) and food availability (i.e., feeding success; Southward and Barrett 1983, Gray 1996). Sardines are visual predators that generally feed during the day (Blaxter 1969, Conway et al. 1994). In the northwest Mediterranean larvae feed in the region of highest food concentration near the surface during the day and passively sink at night (Olivar et al. 2001), while Iberian-Atlantic larval sardines exhibit the opposite behavior whereby they surface at night, and sink during the day (Santos et al. 2006). In our simulations, the DVM3 was modeled from the sardine behavior in the northwest Mediterranean, which could explained the higher simulated mortalities observed than those with the DVM schemes (DVM1 and DVM2) based on the western Iberian Peninsula 
observations by Santos et al. /(2006). Thus, it seems that larval sardines have a DVM strategy driven by food availability (Olivar et al. 2001, Santos et al. 2006). This DVM behavior (simulated by DVM1 and 2) may be driven by the effort to avoid visual predators or harsh solar radiation (Haney 1988, Rhode et al. 2001, Carr et al. 2008). It is unlikely that sardines in this region follow DVM 1 or 2 to avoid being transported offshore, as there is higher mortality with these schemes than without, but there may be a tradeoff for which being in the surface region where nutrients and productivity are concentrated compensates for increased risk of offshore transport (Haney 1988, Carr et al. 2008) and the retention mechanism as proposed by Santos et al. (2004). Although this study does not investigate survival of larvae based on food availability, it will be a topic for future research.

\section{Egg buoyancy}

The buoyancy of eggs significantly affects the retention and recruitment of simulated larvae and acts similarly to release depth. Eggs that are less dense float to the surface as soon as they are released, which is similar to being released in the top $20 \mathrm{~m}$. Eggs that are denser are either neutrally or negatively buoyant and are subject to the flow at the depth where they were released or deeper. Thus, less dense eggs are subject to the seasonality of the surface layer, with higher recruitment in the winter than the summer due to the effect of wind and surface circulation. In winter, surface transport is relaxed, and even buoyant eggs have a chance to settle. Maternal effects may also be significant as female condition changes throughout the spawning season, modifying the fatty acid content of eggs (Garrido et al. 2007), thus influencing egg buoyancy and, subsequently, retention and recruitment. 


\section{FINAL REMARKS}

In this first modeling approach to the factors that influence the recruitment success of $S$. pilchardus in the northern Canary Current Upwelling System (Iberian Peninsula Atlantic coast) we focus on the influence of transport and retention of early life stages using average ocean conditions during a 20 years period. Our results help explain how these small pelagic fish have adapted their reproductive strategies in a coastal upwelling system to ensure coastal retention and recruitment success. In the future it is necessary to study the influence of other factors that are important for larval survival, such as food availability and predation, but also what are the explicative mechanisms for the fluctuations in abundance of sardine in this upwelling system and their inter-annual variability. For this we need to conduct process oriented simulations that capture the fine-scale coastal circulation patterns and new biological parameterizations. Presently, there are already very realistic hydrodynamical models developed for the region (e.g., Tanner et al 2017; Lamas et al. 2017) but the coupling with NPDZ models is still in its infancy in this region (e.g., Reboreda et al 2014). Results from several laboratory experiments about sardine biological traits are now available regarding larvae feeding (Caldeira et al. 2014, Garrido et al. 2016), growth (Moyano et al. 2014; Garrido et al. 2016), mortality (Garrido et al. 2015a, 2016), predation (Pereira et al 2014) and swimming (Silva et al. 2014) but also regarding egg predation and adults feeding and competition with other fish species (Garrido et al. 2008, 2015b; Costalago et al. 2015). The final goal is to develop an end-to-end model for sardine in the northern Canary Current Upwelling System to support sardine fisheries management decisions using a ecosystembased approach. This is of crucial importance since a decreasing trend in sardine productivity has been observed in recent decades, and sardine biomass and recruitment have been at historical lowest values. 


\section{ACKOWLEDGMENTS}

This study was supported by the Portuguese Science and Technology Foundation (Fundação para a Ciência e Tecnologia - FCT) through the research project "MODELA - Modelling larval fish dynamics and related ocean processes" (PTDC/MAR/098643/2008) and "MedEx Inter-basin exchange in the changing Mediterranean Sea: Impact on the ecosystems in the vicinity of the Straits connecting the Mediterranean Sea with the adjacent Basins" (MARINERA/MAR/0002/2008), coordinated by AMPS and AP, respectively. MedEx is also a project of the EC FP6 ERA-NET Program. This study also contributes to the FCT funded Strategic Project Pest-OE/MAR/UI0199/2011 and UID/Multi/04326/2013. SG was supported by FCT throughout research contract IF/01546/2015. ATM was supported by FCT throughout the $\mathrm{PhD}$ grant SFRH/BD/40142/2007. We would like to thank the Institut de recherche pour le développement (IRD) at the Centre de Recherche Halieutique Méditerranéenne et Tropicale (CRHMT) for hosting AEN during this study. 


\section{REFERENCES}

Ambar I. and Howe M.R. (1979) Observations of the Mediterranean outflow — I. Mixing in the Mediterranean outflow. Deep-Sea Res., 26A: 535-554

Arístegui J., Barton E.D., Álvarez-Salgado X.A., Santos A.M.P., Figueiras F.G., Kifani S., Hernández-León S., Mason E., Machú E., and Demarcq H. (2009). Sub-regional ecosystem variability in the Canary Current upwelling. Prog. Oceanogr. 83: 33-48.

Baibai T., Oukhattar L., Quinteiro J.V., Mesfioui A., Rey-Mendez M., and Soukri, A. (2012) First global approach: morphological and biological variability in a genetically homogeneous population of the European pilchard, Sardina pilchardus (Walbaum, 1792) in the North Atlantic coast. Rev. Fish. Biol. Fisher. 22: 63-80.

Bakun A. (1996) Patterns in the ocean: ocean processes and marine population dynamics. California Sea Grant College System, National Oceanic and Atmospheric Administration, in cooperation with Centro de Investigaciones Biológicas del Noroeste, La Paz, 323 pp.

Bakun A. and Parrish R.H. (1982) Turbulence, transport, and pelagic fish in the California and Peru current systems. CalCOFI Rep. 23: 99-112.

Bernal M., Borchers D.L., Valdes L., de Lanzós A.L., and Buckland S.T. (2001) A new ageing method for eggs of fish species with daily spawning synchronicity. Can. J. Fish. Aquat. Sci. 58: $2330-2340$. 
Bernal M., Stratoudakis Y., Coombs S., Angelico M., de Lanzs A.L., Porteiro C., Sagarminaga Y., Santos M., Uriarte A., Cunha E., Valdés L., Borchers D. (2007). Sardine spawning off the European Atlantic coast: characterization of and spatio-temporal variability in spawning habitat. Prog. Oceanogr. 74(2-3): 210-227

Blaxter J.H.S. (1969) Development: Eggs and Larvae. In: Fish physiology 3: 177-252.

Borges M.F., Groom S., Pestana G., and Santos A.M.P. (1997) Is the decreasing recruitment of pelagic fish (sardine and horse mackerel) on the Portuguese continental shelf (ICES Division IXa) induced by a change of environmental conditions? ICES CM 1997/T: 25.

Borges M. F., Santos A. M. P., Crato N., Mendes H., and Mota B. (2003) Sardine regime shifts off Portugal: a time series analysis of catches and wind conditions. Scientia Marina 67(S1): 235-244.

Botsford L.W., Brumbaugh D.R., Grimes C., Kellner J.B., Largier J., O’Farrell M.R., Ralston S., Soulanille E., and Wespestad V. (2009) Connectivity, sustainability, and yield: bridging the gap between conventional fisheries management and marine protected areas. Rev. Fish Biol. Fisher. 19: 69-95.

Brochier T., Lett C., Tam J., Fréon P., Colas F., Ayón,P. (2008a). An individual-based model study of anchovy early life history in the northern Humboldt Current system. Prog. Oceanogr. 79: 313-325.

Brochier T., Ramzi A., Lett C., Machu E., Berraho A., Fréon P., and Hernández-León S. 
(2008b) Modelling sardine and anchovy ichthyoplankton transport in the Canary Current System. J. Plankton Res. 30: 1133-1146.

Brochier T., Mason E., Moyano M., Berraho A., Colas F., Sangrà P., Hernández-León S., Ettahiri O., Lett C. (2011). Ichthyoplankton transport from the African coast to the Canary Islands. J. Mar. Sys. 87: 109-122.

Brochier T., Echevin V., Tam J., Chaigneau A., Goubanova K. and Bertrand A. (2013). Climate change scenarios experiments predict a future reduction in small pelagic fish recruitment in the Humboldt Current system. Global Change Biology 19: 1841-1853.

Caldeira C., Santos A.M.P., Ré P., Peck M.A., Saiz E., and Garrido S. (2014) Effects of prey concentration on ingestion rates of European sardine Sardina pilchardus larvae in the laboratory. Mar. Ecol. Prog. Ser. 517: 217-228.

Carr S.D., Capet X.J., McWilliams J.C., Pennington J.T., and Chavez F.P. (2008) The influence of diel vertical migration on zooplankton transport and recruitment in an upwelling region: estimates from a coupled behavioral-physical model. Fish. Oceanogr. 17: $1-15$.

Carrera P. and Porteiro C. (2003) Stock dynamic of the Iberian sardine (Sardina pilchardus, W.) and its implication on the fishery off Galicia (northwestern Spain). Sci. Mar. 67: 245258.

Checkley D., Ayon P., Baumgartner T.R., Bernal M., Coetzee J.C., Emmett R., Guevara R., 
Hutching L., Ibaibarriaga L., Nakata H., Oozeki Y., Planque B., Schweigert J., Stratoudakis Y. and Van der Lingen C.D. (2010) Habitats. pp. 12-44 In: Climate Change and Small Pelagic Fish. D. Checkley, J. Alheit, Y. Oozeki, and C. Roy (eds) Cambridge University Press, Cambridge.

Chlaida M., Kifani S., Lenfant P., and Ouragh L. (2006) First approach for the identification of sardine populations Sardina pilchardus (Walbaum 1792) in the Moroccan Atlantic by allozymes. Mar. Biol. 149: 169-175.

Chlaida M., Laurent V., Kifani S., Benazzou T., Jaziri H., and Planes S. (2009). Evidence of a genetic cline for Sardina pilchardus along the Northwest African coast. ICES J. Mar. Sci. 66: $264-271$.

Conway D.V.P., Coombs S.H., De Puelles M.F., and Tranter P.R.G. (1994) Feeding of larval sardine, Sardina pilchardus (Walbaum), off the north coast of Spain. B. Instit. Esp. Oceanogr. 10: 165-176.

Coombs S.H., Boyra G., Rueda L.D., Uriarte A., Santos M., Conway D.V.P., and Halliday N.C. (2004) Buoyancy measurements and vertical distribution of eggs of sardine (Sardina pilchardus) and anchovy (Engraulis encrasicolus). Mar. Biol. 145: 959-970.

Coombs S.H., Smyth T.J., Conway D.V.P., Halliday N.C., Bernal M., Stratoudakis Y., and Alvarez P. (2006) Spawning season and temperature relationships for sardine (Sardina pilchardus) in the eastern North Atlantic. J. Mar. Biol. Assoc. UK. 86: 1245-1252. 
Costalago D., Garrido S., and Palomera I. (2015) Comparison of the feeding apparatus and diet of European sardines Sardina pilchardus of Atlantic and Mediterranean waters: ecological implications. J. Fish Biol. 86(4): 1348-1362.

Cowen R.K., Gawarkiewicz G., Pineda J., Thorrold S.R. and Werner F.E. (2007) Population connectivity in marine systems an overview. Oceanography 20(3): 14-21.

Cunha, M. E., Figueiredo, I., Farinha, A., and Santos, A.M.P. (1992) Estimation of sardine spawning biomass off Portugal by the Daily Egg Production Method. Bol. Inst. Esp.Oceanogr., 8(1): 139-153.

Cury P., and Roy C. (1989) Optimal environmental window and pelagic fish recruitment success in upwelling areas. Can. J. Fish. Aquat. Sci. 46: 670-680.

Cury P., Bakun A., Crawford R.J., Jarre A., Quinones R.A., Shannon L.J. and Verheye H.M. (2000) Small pelagics in upwelling systems: patterns of interaction and structural changes in "wasp-waist" ecosystems. ICES J. Mar. Sci. 57(3): 603-618.

Debreu L., Marchesiello P., Penven P., and Cambon G. (2011) Two-way nesting in splitexplicit ocean models: algorithms, implementation and validation. Ocean Model. 49-50: 121.

Dopolo M.T., Van der Lingen C.D., and Moloney C.L. (2005) Stage-dependent vertical distribution of pelagic fish eggs on the western Agulhas Bank, South Africa. Afr. J. Mar. Sci. 27: $249-256$. 
Fage L. (1920) Engraulidae-Clupeidae. Report on the Danish Oceanographic Expeditions 1908-1910 to Mediterranean and Adjacent Seas. 2. Biology. 137 pp.

FAO (1985) Rapport de la troisieme reunion de Groupe de Travail Ad Hoc sur la Sardine Sardina pilchardus Walb. FAO Fishery Comm. for the Eastern Cent. Atlantic, Rome, COPACE/PACE Ser, 85-39, 157 pp.

Ferreira-Priegue E. (1998) O Desenvolvemento da actividade pesqueira dende a alta Idade Media ó século XVII. pp. 51-86 In: Historia de Pesca en Galicia. C. Fernández Cassanova (ed.) Servicio de Publicacións e Intercambio Científico de Universidade de Santiago de Compostela, Santiago de Compostela (in Spanish).

Figueiredo I.M., and Santos A.M.P. (1989) Reproductive biology of Sardina pilchardus (Walb.): seasonal maturity evolution (1986 to 1988). ICES CM 1989/H: 40, 4 pp.

Fiechter J., Rose K.A., Curchitser E.N., Hedstrom K.S. (2015) The role of environmental controls in determining sardine and anchovy population cycles in the California Current: Analysis of an end-to-end model. Prog. Oceanogr. 138(Part B): 381-398.

Fletcher W.J. and Sumner N.R. (1999) Spatial distribution of sardine (Sardinops sagax) eggs and larvae: an application of geostatistics and resampling to survey data. Can. J. Fish. Aquat. Sci. 56: 907-914. 
Frouin R., Fiúza A.F., Ambar I., and Boyd T.J. (1990) Observations of a poleward surface current off the coasts of Portugal and Spain during winter. J. Geophys. Res. 95: 679-691.

Furnestin, J., and Furnestin, M. L. (1953) La reproduction de la sardine et de l'anchois des côtes atlantiques du maroc (saisons et aires de ponte). Revue des Travaux de l'Institut des Pèches Maritimes 23(1), 79-104 (in French).

Ganias K., and Nunes C. (2011) Bathymetric segregation of spawning stages in the Atlantic sardine, Sardina pilchardus. Mar. Ecol. Prog. Ser. 428: 235-244.

Garcia, A., Pérez de Rubin, J., and Rodriguez, J. M. (1988) La distribución de las áreas de puesta de la sardina (Sardina pilchardus (Walb.)) en el sector noroccidental costero del Mar de Alboran en marzo de 1982. Informes Técnicos del Instituto Español de Oceanografia 56: 1-24 (in Spanish).

García-García L.M., Ruiz-Villarreal M., and Bernal M. (2016) A biophysical model for simulating early life stages of sardine in the Iberian Atlantic stock. Fish. Res. 173: 250-272.

García-Lafuente J., Delgado J., Criado-Aldeanueva F., Bruno M., del Río J., and Vargas J. M. (2006) Water mass circulation on the continental shelf of the Gulf of Cádiz. Deep Sea Res. II 53(11): 1182-1197.

Garcia-Soto C., Pingree R. D., and Valdés L. (2002) Navidad development in the southern Bay of Biscay: climate change and swoddy structure from remote sensing and in situ measurements. J. Geophys. Res. 107: 3118, doi:10.1029/2001JC001012. 
Garrido S., Ben-Hamadou R., Oliveira P. B., Cunha M. E., Chícharo M. A., and van der Lingen C. D. (2008) Diet and feeding intensity of sardine Sardina pilchardus: correlation with satellite-derived chlorophyll data. Mar. Ecol. Prog. Ser. 354: 245-256.

Garrido S., Ben-Hamadou R., Santos A.M.P., Ferreira S., Teodósio, M.A., Cotano U., Irigoien X., Peck M., Saiz E., and Ré P. (2015a) Born small, die young: Intrinsic, size selective mortality in marine larval fish. Nature Scientific Reports, 5: 17065.

Garrido S., Cristóvão, A., Caldeira, C., Ben-Hamadou, R., Baylina, N., Batista, H., Saiz, E., Peck, M.A., Ré, P., and Santos, A.M.P. (2016) Effect of temperature on the growth, survival and foraging behaviour of Sardina pilchardus larvae. Mar. Ecol. Prog. Ser. 559: 131-145.

Garrido S, Rosa R., Ben-Hamadou R., Cunha M.E., Chicharo M.A., and van der Lingen C.D. (2007) Effect of maternal fat reserves on the fatty acid composition of sardine (Sardina pilchardus) oocytes. Comp. Biochem. Physiol. B 148: 398-409.

Garrido, S., Santos, A.M.P., dos Santos, A., and Ré, P. (2009) Spatial distribution and vertical migrations of fish larvae communities off northwestern Iberia sampled with LHPR and Bongo nets. Estuar. Coast. Shelf Sci. 84: 463-475.

Garrido S., Silva A., Marques V., Figueiredo I., Bryère P., Mangin A., and Santos A.M.P. (2017) Temperature and food-mediated variability of European Atlantic sardine populations. Under revision Prog. Oceanogr. (submitted Sept. 2016). 
Garrido S., Silva A., Pastor J., Dominguez R., Silva A.V., and Santos A.M. (2015b) Trophic ecology of pelagic fish species off the Iberian coast: diet overlap, cannibalism and intraguild predation. Mar. Ecol. Prog. Ser. 539: 271-285.

Gliwicz M. Z. and Pijanowska J. (1988) Effect of predation and resource depth distribution on vertical migration of zooplankton. B. Mar. Sci. 43: 695-709.

Gonzalez, E. G., and Zardoya, R. (2007) Relative role of life-history traits and historical factors in shaping genetic population structure of sardines (Sardina pilchardus). BMC Evol. Biol. 7:197. doi: 10.1186/1471-2148-7-197.

Gray C.A. (1996) Do thermoclines explain the vertical distributions of larval fishes in the dynamic coastal waters of south-eastern Australia? Mar. Freshw. Res. 47:183-190.

Guisande C., Cabanas J.M., Vergara A.R. and Riveiro I. (2001) Effect of climate on recruitment success of Atlantic Iberian sardine Sardina pilchardus. Mar. Ecol. Prog. Ser. 223: $243-250$.

Han B.P.and Straškraba M. (2001) Control mechanisms of diel vertical migration: theoretical assumptions. J. Theor. Biol. 210: 305-318.

Haney J.F. (1988) Diel patterns of zooplankton behavior. Bull. Mar. Sci. 43: 583-603.

Haynes R. and Barton E.D. (1990) A poleward flow along the Atlantic coast of the Iberian Peninsula. J. Geophys. Res. 95: 11425-11441. 
Haynes R., Barton E.D., and Pilling I. (1993) Development, persistence and variability of upwelling filaments off the Atlantic coast of the Iberian Peninsula. J. Geophys. Res. 98: 22681-22692.

Huggett J., Fréon P., Mullon C. and Penven P. (2003) Modelling the transport success of anchovy Engraulis encrasicolus eggs and larvae in the southern Benguela: the effect of spatio-temporal spawning patterns. Mar. Ecol. Prog. Ser. 250: 247-262.

Kifani S. (1998) Climate Dependent Fluctuations of the Moroccan Sardine and their Impact on Fisheries. pp.235-248 In: Global versus local changes in upwelling systems. M.H. Durand, P. Cury, R. Mendelssohn, C. Roy, A. Bakun, and D. Pauly, (eds) Orstom editions, Paris.

Koné V., Lett C., Fréon P. (2013) Modeling the effect of food availability on recruitment success of Cape anchovy ichthyoplankton in the southern Benguela upwelling system. African J. Mar. Sci. 35: 151-161.

Kritzer, J. P. and Sale P. F. (2004) Metapopulation ecology in the sea: from Levin's model to marine ecology and fisheries science. Fish Fish. 5: 131-140.

Lamas L., Peliz A., Dias J., Oliveira P.B., Angélico M.M., Castro J.J., Fernandes J.N., Trindade A., and Cruz T. (2017) Diurnal variability of inner-shelf circulation in the lee of a cape under upwelling conditions. Cont. Shelf Res. 143:67-77. 
Lasker R. (1981) The Role of a Stable Ocean in Larval Fish Survival and Subsequent Recruitment. Marine fish larvae: morphology, ecology, and relation to fisheries: 81-87.

Laurent V., Caneco B., Magoulas A., and Planes S. (2007) Isolation by distance and selection effects on genetic structure of sardines Sardina pilchardus Walbaum. J. Fish. Biol. 71: 1-17.

Lett C., Verley P., Mullon C., Parada C., Brochier T., Penven P., and Blanke B. (2008) A Lagrangian tool for modelling ichthyoplankton dynamics. Environ. Modell. Softw. 23: 12101214.

Lett C., van der Lingen C., Loveday B.R., Moloney C.L. (2015). Biophysical models of larval dispersal in the Benguela Current ecosystem. African J. Mar. Sci. 37: 457-465.

Lowerre-Barbieri S., DeCelles G., Pepin P., Catalán I.A., Muhling B., Erisman B., Cadrin S.X., Alós J., Ospina-Alvarez A., Stachura M.M., Tringali, M.D., Burnsed S.W. and Paris C.B. (2017). Reproductive resilience: a paradigm shift in understanding spawner-recruit systems in exploited marine fish. Fish and Fisheries 18(2): 285-312.

Malta T., Santos P. T., Santos A. M. P., Rufino M., and Silva A. (2016) Long-term variations in Ibero-Atlantic sardine (Sardina pilchardus) population dynamics: Relation to environmental conditions and exploitation history. Fish. Res. 179: 47-56.

Matsuoka M. and Konishi Y. (1996) Morphological characteristics of unfertilized eggs of the Japanese sardine [Sardinops melanostictus], compared with fertilized ones. Fish. Sci. 62: 855-859. 
Miller D.C.M., Moloney C.L., van der Lingen C.D., Lett C., Mullon C., Field J.G. (2006) Modelling the effects of physical-biological interactions and spatial variability in spawning and nursery areas on transport and retention of sardine eggs and larvae in the southern Benguela ecosystem. J. Mar. Syst. 61: 212-229.

Mbaye B.C., Brochier T., Echevin V., Lazar A., Lévy M., Mason E., Gaye A.T., Machu E., (2015) Do Sardinella aurita spawning seasons match local retention patterns in the Senegalese-Mauritanian upwelling region? Fish. Oceanogr. 24: 69-89.

Moyano M., Garrido S., Teodósio M.A., and Peck M.A. (2014) Standard metabolism and growth dynamics of laboratory-reared larvae of Sardina pilchardus. J. Fish Biol. 84(4): $1247-1255$.

Nelson C.H., Barazab J., Maldonadoc A., Roderoc J., Escutiaa C., and Barber Jr. J.H. (1999) Influence of the Atlantic inflow and Mediterranean outflow currents on Late Quaternary sedimentary facies of the Gulf of Cadiz continental margin. Mar. Geol. 155: 99-129.

Olivar M.P., Salat J., and Palomera I. (2001) Comparative study of spatial distribution patterns of the early stages of anchovy and pilchard in the northwestern Mediterranean Sea. Mar. Ecol. Prog. Ser. 217: 111-120.

Oliveira P. B. and Stratoudakis Y. (2008) Satellite-derived conditions and advection patterns off Iberia and northwestern Africa: potential implications to sardine recruitment dynamics and population structuring. Remote Sens. Environ. 112: 3376-3387. 
Parada C., Colas F., Soto-Mendoza S., Castro L. (2012) Effects of seasonal variability in across- and alongshore transport of anchoveta (Engraulis ringens) larvae on model-based pre-recruitment indices off central Chile. Prog. Oceanogr. 92-95: 192-205.

Parrish R.H., Nelson C.S., and Bakun A. (1981) Transport mechanisms and reproductive success of fishes in the California Current. Biol. Oceanogr. 1: 175-203.

Parrish R.H, Serra R, Grant W.S (1989) The monotypic sardines, Sardina and Sardinops: their taxonomy, distribution, stock structure, and zoogeography. Can. J. Fish. Aquat. Sci. 46:2019-2036.

Peliz A., Rosa T.L., Santos A.M.P., and Pissarra J.L. (2002) Fronts, jets, and counter-flows in the Western Iberian upwelling system. J. Mar. Sys. 35: 61-77.

Peliz A. Dubert J., Haidvogel D.B., and Le Cann B. (2003) Generation and unstable evolution of a density-driven eastern poleward current: The Iberian Poleward Current. J. Geophys. Res. 108: 3268.

Peliz A., Santos A.M.P. , Oliveira P.B., and Dubert J. (2004) Extreme cross-shelf transport induced by eddy interactions southwest of Iberia in winter 2001. Geophys. Res. Letters 31: L08301. 
Peliz A., Marchesiello P., Dubert J., Marta-Almeida M., Roy C., and Queiroga H. (2007a) A study of crab larvae dispersal on the Western Iberian Shelf: Physical processes. J. Mar. Sys. 68: $215-236$.

Peliz A., Dubert J., Marchesiello P., and Teles-Machado A. (2007b) Surface circulation in the Gulf of Cadiz: Model and mean flow structure. J. Geophys. Res. 112: C11015.

Peliz A., Marchesiello P., Santos A.M.P., Dubert J., Teles-Machado A., Marta-Almeida M., and Le Cann B. (2009) Surface circulation in the Gulf of Cadiz: 2. Inflow-outflow coupling and the Gulf of Cadiz slope current. J. Geophys. Res. 114: C03011.

Peliz A., Boutov D., Cardoso R., Delgado J., and Soares P. M.M. (2013) The Gulf of CadizAlboran Sea sub-basin: Model setup, exchange and seasonal variability. Ocean Model. 61: 49-67.

Penven P., Echevin V., Pasapera J., Colas F., and Tam J. (2005) Average circulation, seasonal cycle, and mesoscale dynamics of the Peru Current System: A modeling approach. J. Geophys. Res. 110: C10021.

Pereira R., Teodósio M.A., and Garrido S. (2014) An experimental study of Aurelia aurita feeding behaviour: Inference of the potential predation impact on a temperate estuarine nursery area. Estuar. Coast. Shelf Sci. 146: 102-110. 
Pires R. F., Pan M., Santos A. M. P., Peliz A., Boutov D., and dos Santos A. (2013) Modelling the variation in larval dispersal of estuarine and coastal ghost shrimp: Upogebia congeners in the Gulf of Cadiz. Mar. Ecol. Prog. Ser. 492: 153-168.

Pond S. and Pickard G. L. (1978) Introductory dynamical oceanography.Pergamon Press, Oxford, $241 \mathrm{pp}$.

Ré P., Cabral e Silva R., Cunha E., Farinha A., Meneses I., and Moita T. (1990) Sardine spawning off Portugal. Bol. Inst. Nac. Invest. Pescas 15: 31-44.

Ré P. (1984) Evidence of daily and hourly growth in pilchard larvae based on otolith growth increments, Sardina pilchardus (Walbaum, 1792). Cybium 8: 33-38.

Reboreda R., Nolasco R., Castro C.G., Álvarez-Salgado X.A., Cordeiro N.G., Queiroga H., and Dubert J. (2014) Seasonal cycle of plankton production in the Iberian margin based on a high resolution ocean model. J. Mar. Sys. 139: 396-408.

Relvas P., Barton E.D., Dubert J., Oliveira P.B., Peliz A., Da Silva J.C.B., and Santos A.M.P. (2007) Physical oceanography of the western Iberia ecosystem: Latest views and challenges. Prog. Oceanogr. 74: 149-173.

Rhode S.C., Pawlowski M., and Tollrian R. (2001). The impact of ultraviolet radiation on the vertical distribution of zooplankton of the genus Daphnia. Nature 412: 69-72. 
Santos A.J., Nogueira J., and Martins H. (2005) Survival of sardine larvae off the Atlantic Portuguese coast: a preliminary numerical study. ICES J. Mar. Sci. 62(4): 634-644.

Santos A.M.P., Borges M.F., and Groom S. (2001) Sardine and horse mackerel recruitment and upwelling off Portugal. ICES J. Mar. Sci. 58(3): 589-596.

Santos A.M.P., Peliz A., Dubert J., Oliveira P.B., Angelico M.M., and Ré P. (2004) Impact of a winter upwelling event on the distribution and transport of sardine eggs and larvae off Western Iberia: a retention mechanism. Cont. Shelf Res. 24: 149-165.

Santos A.M.P., Ré P., Dos Santos A., and Peliz A. (2006) Vertical distribution of the European sardine (Sardina pilchardus) larvae and its implications for their survival. J. Plankton Res. 28: $523-532$.

Santos A.M.P., Chicharo A., Dos Santos A., Moita T., Oliveira P.B., Peliz A., and Ré P. (2007) Physical-biological interactions in the life history of small pelagic fish in the Western Iberia Upwelling Ecosystem. Progr. Oceanogr. 74: 192-209.

Santos M.B., González-Quirós R., Riveiro I., Cabanas J.M., Porteiro C. and Pierce G. J. (2012) Cycles, trends, and residual variation in the Iberian sardine (Sardina pilchardus) recruitment series and their relationship with the environment. ICES J. Mar. Sci. 69: 739750. 
Shchepetkin A.F. and McWilliams J.C. (2005) The regional oceanic modeling system (ROMS): a split-explicit, free-surface, topography-following-coordinate oceanic model. Ocean Model. 9: 347-404.

Silva A. (2003) Morphometric variation among sardine (Sardina pilchardus) populations from the northeastern Atlantic and the western Mediterranean. ICES J. Mar. Sci. 60: 13521360.

Silva A., Santos M. B., Caneco B., Pestana G., Porteiro C., Carrera P., and Stratoudakis Y. (2006) Temporal and geographic variability of sardine maturity at length in the northeastern Atlantic and the western Mediterranean. ICES J. Mar. Sci. 63: 663-676.

Silva A., Skagen D.W., Uriarte A., Massé J., Santos M.B., Marques V., Carrera P., Beillois P., Pestana G., Porteiro C., and Stratoudakis Y. (2009) Geographic variability of sardine dynamics in the Iberian Biscay region. ICES J. Mar. Sci. 66: 495-508.

Silva L., Faria A.M., Teodósio M.A., and Garrido S. (2014) Ontogeny of swimming behaviour in sardine Sardina pilchardus larvae and effect of larval nutritional condition on critical speed. Mar. Ecol. Prog. Ser. 504: 287-300.

Sinclair M., and Iles T. D. (1989) Population regulation and speciation in the oceans. ICES J. Mar. Sci. 45(2): 165-175.

Soares P.M.M., Cardoso R.M., de Medeiros J., Miranda P.M.A., Belo-Pereira M., and Espirito-Santo F. (2012) WRF high resolution dynamical downscaling of ERA-Interim for 
Portugal. Clim. Dynam. 39: 1-26.

Southward A.J. and Barrett R.L. (1983) Observations on the vertical distribution of zooplankton, including post-larval teleosts, off Plymouth in the presence of a thermocline and a chlorophyll-dense layer. J. Plankton Res. 5:599-618.

Stenevik E.K., Skogen M., Sundby S., and Boyer D. (2003) The effect of vertical and horizontal distribution on retention of sardine (Sardinops sagax) larvae in the Northern Benguela-observations and modelling. Fish. Oceanogr. 12: 185-200.

Stevenson R.E. (1977) Huelva front and Malaga, Spain, eddy chain as defined by satellite and oceanographic data. Dtsch. Hydrograph. Z. 30: 51-56.

Stratoudakis Y., Coombs S., de Lanzós A.L., Halliday N., Costas G., Caneco B., Franco C., Conway D., Begoña Santos M., Silva A., and Bernal, M. (2007) Sardine (Sardina pilchardus) spawning seasonality in European waters of the northeast Atlantic. Mar. Biol. 152: $201-212$.

Tanner, S. E., Teles-Machado, A., Martinho, F., Peliz, Á., \& Cabral, H. N. (2017). Modelling larval dispersal dynamics of common sole (Solea solea) along the western Iberian coast. Progress in Oceanography, 156, 78-90.

Teles-Machado A., Peliz A., Dubert J., and Sanchez R. (2007) On the onset of the Gulf of Cadiz Coastal Countercurrent. Geophys. Res. Letters. 34: L12601. 
Teles-Machado A., Peliz A., McWilliams J. C., Couvelard X., and Ambar I. (2016) Circulation on the northwestern Iberian Margin: Vertical structure and seasonality of the alongshore flows. Prog. Oceanogr. 140: 134-153.

Watanabe Y., Zenitani H., and Kimura R. (1996) Offshore expansion of spawning of the Japanese sardine, Sardinops melanostictus, and its implication for egg and larval survival. Can. J. Fish. Aquat. Sci. 53: 55-61.

Xu Y., Rose K.A., Chai F., Chavez F.P., Ayón P. (2015) Does spatial variation in environmental conditions affect recruitment? A study using a 3-D model of Peruvian anchovy. Prog. Oceanogr. 138 (Part B): 417-430. 


\section{Highlights}

- Larval sardine retention is highest near the release site (self-recruitment)

- Release area, release depth, and month of release significantly affect recruitment

- Retention and recruitment is very high in relation to other upwelling regions

- Transport to Cantabrian up to 27\%, Morocco up to $1 \%$ and Mediterranean up to $8 \%$

- Results support the idea of a series of metapopulations along this region 